\title{
Conselhos Municipais de Políticas Públicas: uma análise exploratória
}

Marcelo Feijó Martins, Simone Martins, A driel Rodrigues de 0 liveira e Jéferson Boechat Soares

\section{Introdução}

As demandas da sociedade moderna têm imposto desafios cada vez maiores ao poder público no que concerne à qualidade dos serviços públicos e à produção de políticas para setores essenciais e vitais à população. Essas exigências levam à necessidade de modernização dos processos operacionais e administrativos da gestão pública, de modo a oferecer aos cidadãos serviços com qualidade e presteza.

As reivindicações dos movimentos sociais, dos trabalhadores, da igreja e de outros setores da sociedade, durante o período de luta pela redemocratização, foram responsáveis pela mudança comportamental da sociedade brasileira observada nos anos 80.0 conjunto dessas forças deram legitimidade às propostas de descentralização do poder estatal e de democratização da participação no aparato do Estado, contempladas na Constituição de 1988. Começa-se, a partir de então, a construção de uma cultura democrática que prima pela transparência 
da gestão pública, pelo exercício da cidadania e pela inclusão de setores menos favorecidos da população (GoHN, 1997).

As propostas de reforma do Estado trouxeram à tona necessidades urgentes de reformulação da gestão das políticas públicas, objetivando maior eficiência da ação estatal no atendimento das demandas da população. Essa perspectiva exigiu 0 rompimento com velhas estruturas da política tradicional e a incorporação de novos conceitos e processos de gestão que envolvam a sociedade como um todo. Daí surge a importância da construção das estruturas de governança, da capacidade de governar e da efetividade da acoountability para 0 processo.

A Constituição de 1988, tida como a mais cidadã de todas as Constituições brasileiras, regulamentou diversas formas de participação popular. Entre essas está a institucionalização dos Conselhos Gestores de Políticas Públicas, que será objeto de estudo neste trabalho.

Os Conselhos $\mathrm{G}$ estores se apresentam como uma das formas de participação efetiva da sociedade civil e consistem em um espaço no qual se concretiza uma nova relação entre Estado e sociedade na gestão do aparelho público. D e acordo com Fuks et al (2004), os Conselhos Gestores de Políticas Públicas representam uma das principais experiências de democracia participativa no Brasil contemporâneo. Presentes na maioria dos municípios brasileiros, articulados desde o nível federal e cobrindo uma ampla gama de temas saúde, educação, moradia, meio ambiente, transporte, cultura, entre outros - os conselhos são uma conquista inegável do ponto de vista da construção de uma institucionalidade democrática. Sua novidade histórica consiste em apostar na intensificação e na institucionalização do diálogo entre governo e sociedade - em canais públicos e plurais - como condição para uma alocação mais justa e eficiente dos recursos públicos. Os Conselhos apontam para 0 fato de que a dinâmica social deve exercer uma influência significativa sobre as experiências de formulação e implementação de políticas públicas.

A criação e a atuação dos Conselhos $\mathrm{G}$ estores nos municípios adquire, nesse sentido, uma importância fundamental, tanto pela sua potencialidade, enquanto mecanismo de controle público, quanto pela sua função de compor um novo modelo de gestão das políticas (Lubambo, 2002). 0 governo local é a unidade políticoadministrativa que oferece melhores condições para a prática da participação popular na gestão da vida pública. A responsabilidade deliberativa, aliada a situações normativas e controladoras, possibilita aos Conselhos Municipais um significativo papel na construção do desenvolvimento social e econômico local.

Considerando a importância dos Conselhos Gestores no contexto da democratização, da participação e na construção de um novo modelo de gestão das políticas públicas, o presente trabalho busca analisar como eles estão desempenhando suas atribuições precípuas de gestão participativa, transparência, controle público, compromissos com os princípios democráticos e 0 exercício da cidadania. Para tanto, foi realizada uma análise exploratória dos Conselhos G estores de Políticas Públicas instituídos na cidade de Viçosa (MG), apresentando resultados baseados na percepção dos presidentes dos Conselhos, e, complementarmente, nos dados secundários coletados nas sínteses dos relatórios de fiscalização de municípios do estado de Minas $\mathrm{G}$ erais, realizadas pela Controladoria G eral da União (CGU), disponibilizadas no 
site da instituição, correspondendo ao período de 2003 a 2006.

\section{Referencial teónico}

\section{Reforma do Estado: sob a conotação da gestão democrática}

A dinâmica do mundo moderno traz consigo grandes mudanças na sociedade, fazendo-se necessário repensar o papel do Estado, principalmente em um cenário onde os avanços da tecnologia são fortemente destacados. As novas demandas da sociedade exigem do Estado maior qualidade nos serviços prestados, modernização das práticas de gestão pública e uma nova concepção da relação do Estado com a sociedade civil.

Este novo cenário exige gestores públicos capacitados na arte de administrar democraticamente e gerenciar a participação da comunidade. A competência política para conciliar demandas sociais e conviver com as relações de poder entre Estado e sociedade precisa ser aliada à capacidade técnica para definir prioridades e metas, formular estratégias e gerir recursos escassos (KEINERT, 1994, p.46).

É exigível que uma nova filosofia de gestão possibilite a afirmação dessas mudanças, introduzindo valores democráticos e atualizando os mecanismos de gestão, e, por intermédio de aspectos éticos, da participação da sociedade e da democratização da informação, também criar e sugerir novas alternativas (KEINERT, 1994).

Por meio de novos desenhos institucionais, novos mecanismos de gestão, como os Conselhos Gestores, e novas formas de controle, a reforma tende a contribuir não apenas para 0 aumento da eficiência do aparato público, como para sua maior transparência e democratização.
A crise dos anos 80 levou às propostas de reforma do Estado, que deixavam claras as necessidades de se reformular 0 papel estatal. 0 Estado, então, volta-se para a satisfação de necessidades básicas e de novas demandas da sociedade, abandonando definitivamente o modelo intervencionista e permitindo-se maior agilidade e eficiência em suas ações (G UIMARÃES, 2000).

Essa reforma tem múltiplas conotações, alcançando, porém, consensos nos pontos
"As novas
demandas da
sociedade exigem
do Estado maior
qualidade nos serviços
prestados,
modernização
das práticas de
gestão pública e
uma nova concepção
da relação do
Estado com a
sociedade civil."

que tratam da necessidade de o Estado renovar sua própria institucionalidade para poder atender aos anseios da sociedade, bem como naqueles que tangem à publicização do aparato estatal. Publicizar deve implicar nível de incremento da participação da sociedade para um exercício efetivo da cidadania, de maneira a se implementar um Estado reformado que seja realmente democrático. No espaço da reformulação 
das relações Estado-sociedade se faz necessário reestruturar o nexo de relações, de modo a induzir que a sociedade civil participe e exerça, a partir de mecanismos institucionalizados, a gestão compartilhada das políticas públicas e o controle no nível de accountability. Caso contrário, se estará sob o discurso de propostas de reforma pouco efetivas (BRESSER Pereira, 2007).

Uma reforma do Estado não significa desmantelá-lo, pelo contrário, "a reforma jamais poderia significar uma desorganização do sistema administrativo e do sistema político de decisões e, muito menos, é claro, levar à diminuição do seu poder de liderar o processo de mudanças, definindo o seu rumo" (Pereira \& SPINK, 2005, p.15).

A complexificação cada vez maior da sociedade é um fator relevante para 0 obsoletismo de formas tradicionais de gestão dos interesses e dos serviços públicos pelo Estado. A eficiência e a qualidade na prestação de serviços públicos são, muitas vezes, alcançadas por tentativas de inovação na administração pública, ficando claro que as regras de funcionamento democrático da sociedade e das instituições públicas devem ser profundamente reformuladas. Para Bento (2003), governos que asseguram a participação dos cidadãos na elaboração, implementação e avaliação de políticas públicas angariam sustentabilidade política e legitimidade para seus projetos e programas de governo, tornando suas gestões muito mais eficientes do que poderiam ser, se confinadas apenas a equipes de burocratas especializados.

A consolidação do conceito de cidadania e da noção de direitos contribuiu para o fortalecimento da cultura democrática. A corrupção, tida como ação lesiva aos interesses da coletividade em favor do interesse privado, encontra na cidadania um sentimento de repulsa e indignação. A cultura democrática admite o surgimento de propostas de participação da sociedade civil na gestão pública, com o objetivo de alcançar melhor controle sobre a coisa pública (KeINert, 1994).

Não há dúvidas de que, nos dias atuais, o Estado deve concentrar-se na prestação de serviços básicos - saúde, educação, segurança pública, saneamento - bem como no estabelecimento conjunto, com os cidadãos, das prioridades de atendimento. Mas, para bem realizar esse trabalho e efetivamente estar capacitado a atender às necessidades cada vez maiores da população, o Estado precisa estabelecer canais amplos de interlocução com a sociedade, viabilizando a democratização da participação na gestão das políticas e 0 controle público das mesmas.

\section{A construção da participação popular}

Na década de 90, houve uma generalização do tema da "participação". O s mais diversos atores sociais, públicos ou da sociedade reivindicavam e apoiavam a participação social, a democracia participativa, o controle público sobre o Estado e a realização de parcerias entre 0 poder público e a sociedade civil.

Participação, democracia, controle público, parceria, porém, são conceitos com significado diferente para os diversos atores que têm, para cada um deles, uma construção histórica diferente. A generalização e essa divergência de significados impõem a necessidade de se refazer alguns percursos que construíram conceitos e práticas de participação social no País. Inicialmente, pode-se dizer, no entanto, que a participação democrática nas arenas 
públicas que definem os interesses da sociedade brasileira tem sido conquistada a duras penas por esta mesma sociedade (D oImo,1995).

O Estado brasileiro constituiu-sedentro de uma tradição patrimonialista, cultivando relações corporativas com grupos privilegiados e excluindo a grande maioria das pessoas. D esde os primórdios da nossa história política, o povo é mantido à margem do sistema político. Essa exclusão, fruto de uma cultura autoritária e privatista enraizada na tradição política do Brasil, não ocorre, porém, sem a resistência de grupos mobilizados da sociedade e de movimentos sociais que lutam em prol da participação política popular e da inclusão de setores menos favorecidos da sociedade (Carvalho, 1987).

A participação conquistada, ao longo do tempo, pelos diversos tipos de movimentos que marcaram a história de luta política pela democratização e inclusão no País evidenciou em seus respectivos contextos, como protagonista das conquistas, o seu próprio povo. Assim ocorreu com as primeiras resistências indígenas e negras, passando pelas lutas abolicionistas, pela Independência, pela guerra de Canudos, pelas revoltas urbanas contra a miséria e pelos movimentos operários.

A década de 70 foi um período marcado por profundas mudanças econômicas e políticas que provocaram a emergência vigorosa de novas demandas sociais. O Estado autoritário, que se estabeleceu com o regime militar, extinguiu os espaços de expressão e de negociação de interesses e conflitos existentes até então (O’D onnell, 1976). Nesse ambiente de ausência de canais de interlocução e de insatisfação com o regime político instalado surgem novas mobilizações, como a dos metalúrgicos do $\mathrm{ABC}$ paulista, os movimentos estudantis e os ligados às pastorais da Igreja Católica e à classe artística e intelectual do País.

Diante da ausência de espaços legítimos de negociação de interesses e conflitos, esses movimentos tiveram como reivindicação comum a abertura de novos espaços ou arenas para a ação política (SADER, 1988). D esse modo, nos anos 70 e 80 vivenciou-se uma fase de irrupção muito vigorosa de novos movimentos sociais organizados como espaços reivindicativos, de oposição às relações de subordinação, de tutela ou de cooptação pelo regime instituído (SADER, 1988). A partir desses movimentos, constrói-se uma nova cultura de participação popular que se multiplica abrangendo as mais variadas formas de organizações populares.

A emergência dos chamados novos movimentos sociais, que se caracterizou pela colocação de novos temas na agenda política, pela conquista do direito a ter direitos e do direito a participar da gestão da sociedade, culminou com o reconhecimento, na Constituição de 1988, no parágrafo único do seu artigo $1^{\circ}$, de que "todo o poder emana do povo, que 0 exerce por meio de representantes eleitos ou diretamente, nos termos desta Constituição" (Constituição/ 1988, 2000). A Constituição prevê a participação direta dos cidadãos pelos chamados institutos de democracia direta ou semidireta, como o plebiscito, o referendo, a iniciativa popular de lei, os Conselhos e outros canais institucionais de participação popular.

\section{A democratização da participação}

A partir da promulgação da Constituição de 1988, e ao longo da década de 90, as reivindicações dos movimentos sociais pela participação na gestão pública 
ficam cada vez mais evidentes. Passam a objetivar a ampliação de direitos já definidos, a participação na gestão de direitos e interesses, a definição do tipo de sociedade em que se querem incluídos e a construção de uma nova relação da sociedade com o Estado (D AGnino, 1994).

Passam a fazer parte do reordenamento institucional, que se segue à Constituição e à própria Constituinte, diversas reivindicações das lutas dos movimentos sociais. D estacam-se a descentralização do sistema de saúde no País, com a gestão compartilhada e o controle público das políticas do setor, que se articulam desde os Conselhos Gestores locais até 0 Conselho Nacional de Saúde (CARvalho, 1995). Também mereceu atenção da Assembléia Constituinte a questão da reforma urbana, objeto de luta de movimentos pela função social da propriedade e da cidade, regulamentada em capítulo constitucional que prevê o planejamento e a gestão participativa das políticas urbanas, abrindo espaços de co-gestão nas esferas governamentais (So MARRIBA, 1996). A mobilização da sociedade organizada nas áreas de assistência social, de defesa dos direitos da criança e do adolescente, redefinindo de maneira mais universal e democrática essas políticas e possibilitando 0 controle a partir de mecanismos de participação institucionalizados, como os Conselhos Gestores, foi também uma conquista que merece destaque (BoschetTI, 2003). É preciso salientar ainda os orçamentos participativos - que trazem à tona o debate do orçamento municipal, provocado por movimentos sociais - que passaram a ser adotados por dirigentes comprometidos com a eficácia na aplicação dos recursos públicos, com a transparência da gestão orçamentária e com a legitimação e a democratização do governo.
Participar da gestão das questões que dizem respeito ao destino da sociedade é uma conquista que se efetiva a passos lentos. O Estado brasileiro, tradicionalmente caracterizado pelas relações de vínculo com as elites, começa timidamente a ceder espaços, tornando-se mais permeável a uma sociedade civil organizada, articulada, que constitui espaços públicos nos quais reivindica opinar e interferir sobre a política e sobre a gestão do destino comum da sociedade.

A participação na gestão dos interesses coletivos passa, então, a adquirir o significado de participação da sociedade no governo, disputando espaço tanto no aparato governamental quanto na definição das políticas públicas. Significa pôr em questionamento o monopólio do Estado como gestor da coisa pública. Significa ainda construir espaços públicos não estatais, afirmando a importância do controle público sobre o Estado, da gestão participativa, da co-gestão, dos espaços de interação de Estado e sociedade (GENRO, 1995). Essa é a proposta de participação social que se consolida no Brasil na década de 90 .

A ampliação da cidadania para além dos limites dos direitos regulamentados, o exercício da cidadania ativa, permitindo bem mais que o exercício do sufrágio universal do voto, a disseminação de novos canais democráticos, viabilizando a possibilidade de participação da sociedade, são conquistas dos movimentos sociais que quebram uma cultura de exclusão e abrem caminho para a democratização e a participação nas arenas públicas (BonfIM, 2000).

0 aumento das possibilidades de gestão participativa das políticas públicas não estagna, porém, o sentido da participação, embora talvez seja sua dimensão principal nos anos 90. A participação 
na gestão dos interesses públicos da sociedade representa também a explicitação de diferenças e conflitos, a disputa na sociedade pelos critérios de validade e legitimidade dos interesses em questão, os parâmetros sobre o que é justo e injusto, certo e errado, permitido e proibido, o razoável e o não razoável, mostrando que é possível superar posturas privatistas e corporativas arraigadas e construir uma visão plural de bem público. Participar da gestão dos interesses da sociedade é participar da edificação da esfera pública, é consolidar novos espaços de poder (Telles, 1994).

Tão importante quanto a construção dos espaços de gestão participativa foi a construção de uma cultura participativa, que admite, reivindica e valoriza a participação direta e o controle público por parte dos usuários e outros segmentos interessados nas políticas públicas.

\section{Conselhos Gestores}

Os Conselhos de G estão de Políticas Públicas são órgãos colegiados e paritários entre governo e sociedade. Disseminaramse pelo Brasil na década de 90, a partir de sua regulamentação constitucional, materializando a ampliação da participação da sociedade nos espaços públicos. Sua importância para 0 debate sobre 0 aprofundamento do processo democrático aumenta na medida em que se observa a sua presença nos três níveis de governo e de forma especial no âmbito dos municípios (Santos, 2000). A pressão exercida pelos movimentos organizados da sociedade em busca de uma participação no sistema político gerou uma demanda (input) por uma política pública que atendesse a essa necessidade. 0 Conselho Gestor foi um output resultante da atividade política, materializado e institucio- nalizado por meio dos mecanismos legais vigentes pós-ditadura militar.

Os Conselhos G estores possibilitam a participação da sociedade civil nas discussões sobre o planejamento e na gestão das diversas políticas estatais responsáveis pela promoção de direitos fundamentais centrados em diferentes áreas: saúde, assistência social, educação, trabalho, moradia, entre outros.
"O Estado

brasileiro,

tradicionalmente

caracterizado pelas

relações de vínculo

com as elites, começa

timidamente a ceder

espaços, tornando-se

mais permeável a

uma sociedade civil

organizada ..."
De acordo com Gohn (1997) apud Santos (2000, p.137-138), "0 escopo de deliberações dos Conselhos é bastante amplo. Suas decisões devem incidir sobre o formato das políticas públicas e sobre as estratégias e diretrizes para implementação das mesmas". Por isso, devem, além de definir metas e diretrizes políticas em relação à universalização de direitos e às políticas de atendimento estabelecidas nos 
direitos sociais, deliberar sobre 0 formato de gestão de maneira a garantir o controle público sobre o governo (SANTOS, 2000).

Nesse sentido, o Conselho tem a prerrogativa de aprovar ou não a realização de convênios, impedir a prestação de serviço de determinada instituição que não obedecer aos requisitos previstos em lei, aceitar ou rejeitar as prestações de contas dos gastos orçamentários, definir procedimentos de democratização de informações e das decisões por meio da universalidade do acesso às atividades e ações do governo (SAntos, 2000). Eles ainda fortalecem o processo descentralizador das políticas sociais, na medida em que viabilizam a produção, o acompanhamento e o controle das políticas pelos próprios cidadãos.

A competência de cada Conselho G estor reserva a tais órgãos a prerrogativa de intervir na promoção, defesa e divulgação dos direitos e interesses coletivos relacionados às suas áreas de atuação, conforme os moldes previstos na legislação que os constituiu. D essa forma, os temas discutidos por um Conselho devem ser todos voltados ou interligados à sua área específica, conforme 0 setor público objeto de seu funcionamento, não obstante a possibilidade de interface com outros Conselhos no caso de discussões de políticas intersetoriais.

As leis que criam os Conselhos sinalizam alguns elementos importantes para analisar a representação social, pois estipulam normas que definem quem pode participar, sobre o que se delibera e qual o tipo de relação existente entre o Conselho e a administração pública. Os Conselhos são mecanismos nos quais os cidadãos participam por meio de instituições ou organizações. Eles são compostos paritariamente por membros governamentais e não-governamentais, à exceção dos Conselhos de Saúde e de Emprego, que são tripartites (SANTOS, 2000).

As instituições e organizações nãogovernamentais devem ser eleitas em fórum próprio do segmento social que representam, sem a interferência do Estado. A autonomia da sociedade civil para escolher seus representantes é um princípio básico para a garantia da representação social. A legitimidade das instituições e organizações da sociedade de se candidatarem a uma vaga no Conselho coloca outros aspectos para a questão da representatividade: 0 tipo do trabalho realizado, a contribuição no debate político ou até mesmo a disposição de participar de articulações com outras organizações e instituições. A eleição das entidades representativas em fórum próprio aponta para um tipo de representação que vai além da própria instituição do conselheiro, assumindo a noção de que este precisa se legitimar diante de um segmento social específico para representá-lo como tal (SAntos, 2000).

Os Conselhos G estores estão presentes nas três esferas de governo. No âmbito federal, as áreas básicas em que atuam são emprego, educação, saúde, criança e adolescente, assistência social e habitação. No âmbito dos estados e municípios, são contemplados, ainda, outros setores, como política urbana, política agrícola, cultura, população negra, portadores de deficiências físicas, idosos, meio ambiente e direitos das mulheres (G oHN, 2003).

A instituição dos Conselhos Gestores é importante porque há repasses de verbas do governo federal para estados e municípios, e também dos estados para os municípios, que estão atreladas à existência desses mecanismos nos respectivos entes governamentais. 
Quanto ao seu poder de decisão, os Conselhos podem ser deliberativos ou consultivos. O Conselho deliberativo é aquele que possui o poder de discutir e decidir sobre os rumos das políticas públicas executadas pelo governo, e 0 consultivo tem como função emitir pareceres e dar sugestões sobre as políticas, não possuindo poder decisório. A prerrogativa deliberativa de um Conselho Gestor lhe concede a capacidade de sustentar um papel ainda mais eficaz no auxílio do Poder Legislativo, em sua função de controle da Administração Pública, do que um Conselho de caráter meramente consultivo, não obstante as pressões que este pode gerar ea sua relevância como instância participativa. Complementa-se, ainda, que a imperatividade resguardada pela força da lei nos Conselhos deliberativos qualifica, em tese, o resultado, baseado nas suas decisões discutidas e consumadas (NorONHA, 2000). Desse modo é que se identificam como mecanismos de controle tanto da ótica política, como da pública.

O controle público apresenta uma conotação mais pragmática quanto aos assuntos que devem compor a pauta de discussão dos Conselhos, objetivando a produção de resultados que convergem no encontro dos interesses públicos de fato. No tocante ao controle político, a contribuição que a participação popular nesses Conselhos promove se dá no sentido de atuar no campo da fiscalização, buscando a probidade na gestão pública, atendendo-se ao princípio da moralidade administrativa conforme explicitado na Constituição Federal.

O s Conselhos são fundamentais para que a sociedade possa identificar e expressar quais são seus reais interesses e quais as políticas identificadoras do bem comum, pela prestação de serviços públicos. Esses mecanismos de fortalecimento do controle e de cooperação na gestão das políticas não significam o engessamento da administração pública, mas a ampliação do debate a partir desses canais de comunicação, para a concretização dos aspectos democráticos e republicanos, nos padrões da democracia participativa.

\section{A participação nos Conselhos: limites e potencialidades}

A participação democrática, para fins deste trabalho, será analisada sob os aspectos das práticas participativas nas quais há um compartilhamento da gestão pública entre o Estado e a sociedade.

De todos os mecanismos de participação social e controle público, talvez se possa afirmar que o Conselho Gestor é o mais enraizado na reivindicação dos movimentos sociais.

O enraizamento dos Conselhos nas lutas populares e democráticas lhe dá uma qualidade especial como um dos mecanismos de participação mais permanente, que resiste às mudanças e aos diferentes graus de abertura dos governos à participação social. Há Conselhos sólidos e democráticos instituídos a partir de iniciativas sociais, que persistem na sua atividade, mesmo sem contar com apoio significativo de governos. Mesmo assim, esses Conselhos vêm conseguindo pressionar governos contra atitudes corporativas e excludentes, dispor de funcionários públicos para a realização de suas tarefas administrativas e utilizarimóveis e equipamentos públicos. Essas "conquistas" não passam de direitos legais, mas, especialmente quando se relacionam com governos conservadores, somente são obtidas pela ação de conselheiros muito fortes, articulados e competentes. O s Conselhos, evidentemente, dependem de uma mínima resposta da parte governamental. 
D esprovidos da participação dos representantes governamentais e sem um acesso mínimo às informações do governo, eles deixam de ser espaços de discussão e de co-gestão dos interesses públicos, passando a espaços de luta social reivindicativa, como os demais movimentos sociais (TEIXEIRA, 2000).

A tualmente existem nos municípios brasileiros mais conselheiros que vereadores, o que nos dá a dimensão de uma forma de participação popular muito mais acessível aos cidadãos do que a tradicional representação parlamentar. O s Conselhos G estores são instâncias de formulação depolíticas que possuem um alto conceito de respeitabilidade enquanto espaços transparentes e comprometidos com o interesse público. Eles tornam a política mais pública, pelo menos aqueles onde há participação de representações de segmentos comprometidos com a democratização da gestão dos negócios públicos.

Existem pesados embates travados dentro dos Conselhos por causa da prática da defesa de interesses privados. Q uando se pretende tomar decisões corporativas, clientelistas, costuradas com base em negociatas políticas escusas, trata-se de boicotar, obstruir e desqualificar 0 Conselho. Esse comportamento privatista ocorre quando estão em jogo interesses de grupos de medicina privada, da construção civil, do transporte público, da indústria e do comércio, das escolas particulares ou das grandes entidades assistenciais.

Para que os interesses públicos prevaleçam exige-se tanto transparência quanto livre acesso às informações da gestão estatal e do que se passa no governo. Ainda que não acumule poder para enfrentar as distorções da política, essa transparência relativa e esse conhecimento da máquina e dos caminhos da políticajásão importantes conquistas democráticas da sociedade. A publicização da arena política e 0 fortalecimento de um sentido de interesse público, tanto na sociedade civil quanto nos governantes, são das mais importantes potencialidades dos Conselhos como democratizadores da participação política (GoHN, 2003).

Um requisito fundamental para a eficácia dos Conselhos é a capacitação de seus membros com vista ao exercício mais qualificado da gestão das políticas sociais. Embora os Conselhos sejam frutos das reivindicações dos movimentos pela ampliação da participação e democratização do campo público, é notório que grande parte das representações de movimentos e de outras entidades integrantes dos Conselhos carece de melhor qualificação para exercer a contento as funções de conselheiro (G oHN, 2003).

Os conselheiros não-governamentais, principalmente aqueles que representam entidades populares, têm grandes dificuldades de acesso às informações, aos recursos materiais e ainda ficam na dependência de "favores" do governo. Portanto, é grande a capacidade dos governos de esvaziá-los, seja tomando decisões nos bastidores, seja desprestigiando-os, afastando-se desses espaços ou indicando para os Conselhos membros governamentais pouco representativos, com grande rotatividade e pouca capacidade para discutir e deliberar.

Como conseqüência dessa dependência, há o perigo de ver os conselheiros limitados a assuntos secundários, principalmente face à adoção, por governos, de políticas neoliberais, que têm reduzido consideravelmente os recursos orçamentários e os gastos públicos com políticas sociais (D raibe, 1993). Essa política de desobrigar-se do social assenta-se numa 
postura sistemática de deslegitimação dos espaços de controle público, como os Conselhos Gestores das áreas socioassistenciais, inviabilizando a participação social na definição dos orçamentos dessas áreas.

Outro fator que limita a força dos Conselhos é a falta de mobilização da sociedade. É indispensável aos atores que participam desses espaços públicos contarcom o respaldo social de suas bases representativas. Sem a mobilização da sociedade e de segmentos organizados, fragiliza-se a capacidade de pressão social que garantiriaforça, legitimidade e representatividade nas negociações de interesse público.

Também a grande proliferação de Conselhos acaba segmentando a participação social, setorizando 0 encaminhamento de políticas, reduzindo a capacidade da sociedade de ocupá-los todos com qualidade e, portanto, tornando-os mais eficazes (TEIXEIRA, 2000). Escolher e priorizar os espaços que permitem uma participação mais efetiva pode garantir maior qualidade nessa participação. $\mathrm{O}$ aperfeiçoamento dos Conselhos como espaço de gestão participativa deve levar também à superação dessa multiplicação de espaços estanques, construindo-se espaços de intersetorialidade nos Conselhos.

A análise dos limites e potenciais dos Conselhos aponta alguns desafios, como a qualificação dos atores envolvidos, tanto do governo quanto o da sociedade, bem como a ampliação e a consolidação de uma cultura democrática e sua tradução em métodos e procedimentos concretos que potencializem a gestão compartilhada da sociedade.

A ampliação da eficiência e da eficácia dos espaços de gestão participativa supõe ainda romper a burocracia estatal e disseminar o saber técnico, centralizador de poder no aparato estatal. É necessário também romper a tendência de limitar a participação aos assuntos secundários, deixando de fora do debate democrático assuntos fundamentais (TEIXEIRA, 2000).

0 clientelismo e o corporativismo, no âmago dos Conselhos, também não podem ser considerados como traços de uma cultura política do passado, pois eles ocorrem e se insinuam mesmo entre os novos espaços de democracia participativa.

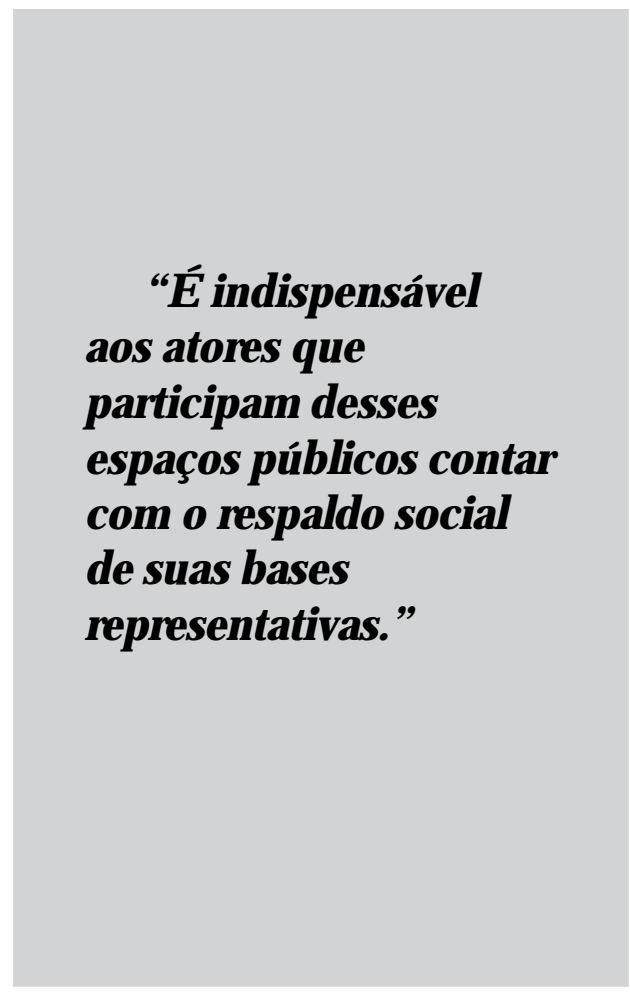

Para assegurar a continuidade, a permanência e 0 aperfeiçoamento da democracia participativa é preciso priorizar práticas menos dependentes da iniciativa governamental, promover 0 fortalecimento do tecido social, identificando e capacitando as representações sociais e outros setores da sociedade, como associações profissionais, igrejas, sindicatos e clubes de serviços sociais, que são atores 
promovedores da cidadania. Contudo, 0 aperfeiçoamento e a continuidade dos processos de gestão democrática e participativa também passam pelas contribuições que acabam acontecendo na relação de conflito entre Estado e sociedade nos espaços de deliberação política (G oнn, 2003).

Descentralização do poder estatal

A partir dos anos 80, o debate sobre a eficácia da gestão das políticas sociais deu destaque à descentralização como instrumento que permite tornar o poder mais transparente e suscetível ao controle público.

A descentralização é entendida como um processo de transferência de poder dos níveis centrais para os periféricos. Não é um conceito novo na literatura especializada e, especificamente no caso do Brasil, surge como reivindicação dos movimentos sociais pela democratização e reforma da estrutura de poder (ARRETCHE, 1999).

Não se deve confundir democratização e participação com descentralização. Esta é um "processo de redistribuição do poder decisório estatal em suas dimensões funcionais ou territoriais", mas não terá sentido se não vier acompanhada pela presença da sociedade civil (RoFmAN, 1990).

A descentralização como um processo que se define de maneira dialética em relação à centralização é a possibilidade de levar a decisão sobre as políticas públicas para o âmbito local, para próximo de seus destinatários.

Nos Conselhos G estores locais visualiza-se como se dá a descentralização da gestão das políticas públicas na esfera municipal. Em nosso país, o município é um ente da federação e, como tal, possui competências definidas pela Constituição para gerenciar essas políticas e as demandas de interesse local (Constituição Federal/ 1988, 2000).

D esse modo, o município passa a desempenhar um novo papel, não dependendo de transferência de poder dos outros níveis de governo, o que agiliza a administração local e impulsiona o seu desenvolvimento. Entretanto, apenas 0 poder formal não é o bastante se os municípios não dispõem dos recursos financeiros necessários à implementação das políticas, os quais estão, na maioria das vezes, nos níveis federal e estadual.

A perspectiva progressista aborda a descentralização como uma estratégia para reestruturar 0 aparato estatal, tornando-o mais ágil e eficaz, democratizando a gestão pela criação de novas instâncias de poder e redefinindo as relações Estado/ sociedade (ARRETChe, 1996). Os novos canais de interlocução entre população e Estado passam a constituir um importante instrumento da gestão pública, evidenciando surpreendentes aspectos da dinâmica política da sociedade.

Com o processo de descentralização, a prestação de serviços públicos locais fica a cargo das ações municipais. Esse novo cenário aponta para a necessidade de se reformular as tradicionais formas da administração pública, compartilhando com a sociedade civil a gestão dos negócios públicos. A descentralização promove a inclusão de segmentos representativos da população, nos espaços de deliberação pública onde os interesses da comunidade são discutidos, de modo que a sociedade passa a compartilhar com 0 poder público as responsabilidades pela gestão das políticas. Essa nova estrutura de gestão possibilita uma ação governamental mais eficiente, uma relação intersetorial mais coordenada nas áreas de atuação pública, com o objetivo de 
proporcionar melhor qualidade de vida à população.

Desse modo, o processo de descentralização passa a contribuir não apenas para melhorar a eficácia da gestão das políticas públicas, mas também para a consolidação da cidadania, da transparência e da democracia.

\section{Governança e governabilidade}

A governança é um termo discutido sob diferentes perspectivas por vários autores. De certa forma, isso é um pouco prejudicial para a análise científica, pois acarreta a imprecisão do termo. Nas opiniões de alguns autores, a ampliação do conceito de governança tem dificultado sua distinção do conceito de governabilidade. É de suma relevância, portanto, precisar 0 seu significado no contexto em que é utilizada.

Para atender às finalidades deste trabalho, faz-se necessário situar e aproximar as concepções de governabilidade e de governança com o contexto da democratização dos espaços públicos e da gestão participativa, de modo que se possa visualizar, com clareza, a inter-relação da parte conceitual e da parte empírica.

A governabilidade está situada no plano do Estado e representa um conjunto de atributos essenciais ao exercício do governo, sem os quais nenhum poder será exercido (D INIz, 1995). Isto é, governabilidade refere-se à capacidade de um governo obter apoios e articular alianças com os vários segmentos sociais, com 0 intuito de viabilizar a implantação de seu programa. A capacidade política de governar ou governabilidade deriva, então, da relação de legitimidade do Estado e do seu governo com a sociedade.

Q uanto à governança, comecemos pela proposição disseminada pelo Banco
Mundial, que introduziu a expressão "governança local", nos anos 90, originada do termo inglês local governance, que era utilizado pelas A gências Internacionais para designar preocupações com o desenvolvimento sustentável das localidades urbanas (Banco Mundial, 2002). 0 objetivo é buscar "os bons resultados" nas administrações públicas locais para postular a geração de melhores práticas pela inovação, participação, eficácia e sustentabilidade. O utro aspecto a ser considerado são os instrumentos mediadores da política distributiva e da necessidade de um processo de descentralização de poder. 0 que se espera é que as localidades possam e devam ser as principais responsáveis pela transformação e fomento da sustentabilidade urbana (Banco Mundial, 2002). Para tanto, é importante 0 aprofundamento da utilização de mecanismos de intermediação da sociedade civil com o Estado como saídas à crise do Estado, em especial no que tange à esfera local, pelo fato de os municípios encontrarem maiores dificuldades financeiras.

A proposição propagada pelo Banco Mundial surge como condição para se constituirum Estado eficiente que contemple a construção do desenvolvimento autosustentável pelo estímulo à inovação, participação social e descentralização das políticas. Ao adquirir, portanto, um caráter de regulação social com vistas à governabilidade, aproxima-se da perspectiva normativa de "bom governo". Nessa linha de pensamento, o Banco Mundial prevê que a localidade, ou seja, o município, será o grande responsável pela convergência das aplicações dos modelos de governança das políticas públicas para lidar com o aumento das exigências de novas demandas da população.

Uma segunda proposição é a chamada "governança democrática”. Essa concepção 
abrange toda tentativa de radicalização dos mecanismos e instrumentos de democracia local (Santos JR., Ribeiro \& Azevedo , 2004). São padrões de interação de governos locais com atores sociais, que estabelecem diretrizes, diagnosticam e coordenam ações públicas a partir de fóruns híbridos, instalados na estrutura de Estado. Esses fóruns são formados em parte por representantes do Estado e em parte por representantes da sociedade civil com poderes consultivos e/ ou deliberativos. Eles possibilitam aos diversos segmentos organizados da sociedade 0 acesso aos espaços de decisão política em que os interesses da comunidade são alvos de discussão. Esses mecanismos participativos vêm, portanto, redefinindo os espaços de gestão das políticas públicas com a adoção do controle público e da gestão compartilhada. Na prática, os Conselhos G estores, regulamentados na Constituição de 1988 e em leis federais, deram grande visibilidade a essa proposição.

A adoção de estruturas de gestão descentralizadas, como é o caso das administrações regionalizadas e de subprefeituras instituídas em cidades de grande porte, também compõem a governança democrática.

O utro tema que aparece como elemento da governança democrática é a intersetorialidade. Ela é vista como uma articulação de saberes e experiências no planejamento, realização e avaliação de ações para alcançar efeito sinérgico em situações complexas, visando ao desenvolvimento social. A intersetorialidade não é um conceito que engloba apenas os aspectos das políticas sociais, mas também a sua inter-relação com outros aspectos da cidade, como sua infra-estrutura e ambiente, que também determinam a sua organização e regulam o modo como se dão as relações entre os diversos setores da sociedade. Esse elemento estabelece uma nova maneira de administrar a cidade, que passa pela identificação dos problemas e pela solução integrada, buscando garantir aos cidadãos seus direitos sociais.

No contexto da governança democrática, propõe-se entender governança como uma nova geração de reformas administrativas e de Estado, que têm como objeto a ação conjunta, levada a efeito de forma eficaz, transparente e compartilhada, pelo Estado, pelas organizações e pela sociedade civil, objetivando uma solução inovadora dos problemas sociais e criando possibilidades e chances de um desenvolvimento futuro vigoroso para todos os participantes (LÖFFER, 2001:212). As estratégias de ações no campo público têm procurado desenvolver e regulamentar novos mecanismos de governança que possibilitam uma participação maior da sociedade nos assuntos públicos.

A prática da governança contempla mecanismos de democracia direta, mecanismos de gestão pública participativa e 0 terceiro setor. Regulamentados em nossa Constituição, os mecanismos de democracia direta - referendo, plebiscito e iniciativa popular de lei - são utilizados em situações especiais, nas quais a sociedade deve manifestar-se sobre determinado assunto ou, ainda, iniciar o processo legislativo (Constituição/ 1988, 2000). Q uando se trata de aplicar os mecanismos de governança no âmbito da gestão pública participativa, objeto de análise deste trabalho, tem-se uma forte tendência a adotar o formato do controle público na administração. Com a institucionalização dos Conselhos $\mathrm{G}$ estores, cria-se uma nova concepção de controle e gestão das políticas públicas, que passam a ser exercidos com o auxílio de segmentos organizados da sociedade. A participação, 
por meio dos Conselhos, tem a grande vantagem de conseguir agregar as necessidades, experiências, prioridades e proximidade dos cidadãos à formulação e execução das políticas públicas, principalmente na esfera municipal (SANTOS JR., Ribeiro \& Azevedo , 2004). No terceiro setor, a perspectiva da governança se estabelece quando da assunção, pelas O rganizações da Sociedade Civil de Interesse Público (O scip), da responsabilidade pela execução dos serviços públicos, que se dá a partir do contrato de gestão com o Estado (Novelli, 2004).

Em relação à esfera local, a governança significa que as cidades fortalecem cada vez mais a cooperação com os cidadãos, as organizações e as entidades sem fins lucrativos na condução de suas ações. A cooperação engloba tanto o trabalho conjunto de atores governamentais e nãogovernamentais quanto novas formas de transferência de serviços para grupos privados e comunitários. A governança, no âmbito municipal, é assim "uma forma autônoma de coordenação e cooperação, por meio de redes interorganizacionais, que podem ser formadas por representantes de organizações políticas e administrativas, associações, poder público, empresas e segmentos organizados da sociedade" (JANN, 2003:449).

Se o conceito de governabilidade remete às condições sistêmicas sob as quais se dá o exercício do poder, ou seja, aos condicionantes do exercício da autoridade política, a governança qualifica o modo de uso dessa autoridade. Compreende, portanto, além das questões políticoinstitucionais de tomada de decisões, os canais de interlocução do Estado com a sociedade, no que diz respeito ao processo de definição, acompanhamento e implementação de políticas públicas (MELo, 1995;
Coelho \& Diniz, 1995). Sendo assim, a natureza da relação entre Estado e sociedade afeta, ao mesmo tempo, os níveis e as formas de governança do Estado e de governabilidade da sociedade.

\section{Controle público}

O controle público deve pressupor uma forma de governar na qual os cidadãos possam atuar como sujeitos políticos capazes de orientar e fiscalizar a ação estatal. Dessa forma, a participação da sociedade no controle público pode ser exercida por meio do acompanhamento e verificação das ações governamentais, pela avaliação dos processos, objetivos e resultados de programas de governo, e a partir da execução das políticas públicas (CARVAlHo, 1995).

Com o controle público, há um avanço em direção à construção de uma sociedade democrática que determina transformações profundas nas formas de relação do aparelho de Estado com o cidadão. A partir da reforma e modernização do aparelho estatal, foi possível criar mecanismos capazes de viabilizar a integração dos cidadãos no processo de definição, implementação e avaliação da ação pública (Banco Mundial, 1999). Desse modo, a reforma contribuiu para o fortalecimento gradual de mecanismos participativos voltados à formulação e avaliação de políticas públicas, viabilizando o controle público dessas políticas.

0 incremento do controle público possibilita um aumento crescente da qualidade dos serviços públicos prestados à sociedade. Além disso, é uma maneira de se estabelecer uma parceria eficaz e gerar, a partir dela, um compromisso entre poder público e população capaz de garantir condições para o desenvolvimento econômico e social. 
Os Conselhos Gestores, institucionalizados a partir da Constituição Federal de 1988, constituem um importante instrumento de controle público. Os Conselhos são fóruns de exercício da gestão participativa e da democracia. A partir deles viabiliza-se a participação popular no desenho das políticas públicas, nas negociações de interesses da coletividade, na elaboração de programas e projetos sociais, bem como na fiscalização das ações governamentais ( $\mathrm{G} \mathrm{oHN}, 2003)$. 0 controle público tem como pressuposto a participação da sociedade na gestão pública, inclusive com atribuições fiscalizatórias das instituições e das ações governamentais em prol dos interesses da população. Uma sociedade organizada exerce inúmeros meios de controle, entre outras possibilidades capazes de promover maior transparência à gestão pública e melhoria da qualidade dos serviços oferecidos aos cidadãos.

O exercício do controle público, enfim, nada mais é do que governar de modo interativo, equilibrando forças e interesses, e transformando o aparelho de Estado em um efetivo instrumento do exercício e da realização da cidadania.

\section{Accountability}

A acoountability se manifesta segundo mecanismos de cobrança e de controle recíprocos que constituem fator favorável ao êxito da gestão pública, impedindo a apropriação da máquina por interesses privados, o desperdício, além da alocação de recursos para fins não previstos (D INIZ \& Azevedo, 1995).

A acoountability pode situar-se em termo das políticas públicas implementadas, de questões administrativas, profissionais, financeiras, morais, legais e constitucionais. Cada uma dessas áreas da accountability dispõe de diferentes mecanismos e objetivos específicos para o controle a ser exercido.

O termo accountability apresenta uma conceituação multidimensional. A definição dada por O 'D onnell (2000) enfatiza que a noção de accountability vertical pressupõe uma ação entre desiguais, seja sob a forma do mecanismo do voto, seja sob a forma do controle burocrático. A dimensão de accountability horizontal, por sua vez, presume uma relação entre iguais, por meio do instrumento de checks and balances (freios e contrapesos), do mútuo controle entre os três poderes independentes do Estado.

Todavia, os mecanismos das eleições e do voto são insuficientes para o controle da ação governamental, assim como a noção de acoountability horizontal é também insuficiente para garantir a legitimidade necessária ao exercício da democracia, apesar de necessária para o tema da governança. A expressão conceitual de soberania popular implicíta na concepção da democracia requer uma base de legitimidade que vai além da existência de mecanismos de chedks and balanoes entre os poderes e também dos tradicionais mecanismos de controle por meio das eleições (CARneiro \& Costa, 2001).

Uma terceira dimensão da noção de accountability, e que se alinha estreitamente com o objeto de análise deste trabalho, é a accountability societal. Sua concepção parte de uma matriz teórica que enfatiza a dicotomia Estado e sociedade civil, comungando dos ideais de que a vigilância da sociedade sobre o governo constitui uma especificidade e merece um destaque à parte das noções de acoountability vertical ou horizontal (G RAU, 2000).

Sinteticamente, a essência da acountability está na questão da republicanização do 
espaço público, na consolidação das diretrizes democráticas de soberania popular e no controle da ação governamental.

Os Conselhos Gestores municipais, estaduais e nacionais constituem experiências de inovação institucional que sinalizam para ampliação dos espaços de deliberação pública e consagram-se como mecanismos de atuação participativa que vão muito além das atuações dos demais instrumentos de participação vigentes, uma vez que são estruturas jurídico-constitucionais, de caráter permanente, com representação paritária entre Estado e sociedade civil e com amplos poderes de controle sobre a política. Portanto, mais do que expressão e mecanismo de mobilização social, os Conselhos acenam para uma nova forma de atuação de instrumentos de accountability societal, visto que apresentam a capacidade de colocar temas na agenda pública, de controlar seu desenvolvimento e de fiscalizar processos de implementação de políticas e direitos, por intermédio de um fórum híbrido, composto de representantes governamentais e não-governamentais.

A prática da boa governança exige, sobretudo, a vigência de instrumentos de acountability que ampliem a abrangência do controle público sobre as ações do governo e solidifiquem os preceitos básicos da democracia e da legitimidade política. A ponta-se ainda a centralidade da participação social no tocanteà construção de uma nova governabilidade democrática, haja vista que esta confere maior legitimidade à ação governamental e amplia o espaço público, enfatizando uma perspectiva sociocêntrica, imprescindível na composição das bases de governabilidade (BAnco Mundial, 2002).

A eficiência estatal, tarefa básica da reconstrução do Estado, depende também dos instrumentos de accountability, especialmente no que concerne à necessidade de os governos prestarem contas à população a respeito do desempenho de seus programas de ação (BANco Mundial, 2002). O s instrumentos de acoountability societal têm o propósito, dessa maneira, no âmbito do desempenho governamental, de romper com a lógica auto-referenciada da burocracia estatal, criando possibilidades de controle do Estado pela sociedade civil. O s conceitos de democracia e de eficiência passam a se inter-relacionar de maneira muito mais estreita a partir da perspectiva de um novo modelo de gestão pública que pressupõe ser o Estado tão mais eficiente quanto mais democrática for a sua administração.

Visto que a accountability tem noções multidimensionais, fica claro que sua efetividade requer a combinação dos diversos modos de responsabilização, entendidos como instrumentos que se complementam para o exercício do controle governamental.

Assim, a efetividade da accountability societal depende de uma sociedade civil organizada e capaz de exercer influência sobre o sistema político e sobre as burocracias públicas, demandando e viabilizando a dimensão associativa da cidadania e da democracia participativa.

\section{Procedimentos metodológicos}

0 estudo foi realizado em março de 2007, em Viçosa (MG ), cidade universitária localizada na Zona da Mata, com 73.121 habitantes residentes, de acordo com 0 censo do IBGE de 2005 (IBGE, 2007). Somando-se esse número a mais 12 mil pessoas da população flutuante constituída de estudantes universitários de graduação e pós-graduação, técnicos em 
treinamento na Universidade Federal de Viçosa, participantes de congressos e eventos técnico-científicos e culturais e outros, chega-se a uma população de mais de 85 mil pessoas (CÂmara Municipal de VIçOSA, 2007).

Para a análise empírica, foram identificados 17 Conselhos G estores municipais, dos quais 12 se encontram em funcionamento e os demais tiveram sua formação inviabilizada pela indisposição das entidades em se fazerem representar.

Para a classificação da pesquisa foi considerado 0 critério adotado por Vergara (1997), que a qualifica em relação a dois aspectos: quanto aos fins e quanto aos meios. A pesquisa caracteriza-se quanto aos fins como exploratória e descritiva. Exploratória porque foi realizada em uma área onde existe pouco conhecimento acumulado. Descritiva porque expõe características de determinada população ou de determinado fenômeno. Quanto aos meios, a pesquisa foi bibliográfica, documental e de campo.

A coleta de dados primários foi realizada por meio da aplicação de questionários semi-estruturados com o objetivo de identificar as características dos Conselhos Gestores no município de Viçosa/ MG e fazer uma avaliação sobre seu desempenho, com base na percepção de seus presidentes. O s questionários foram divididos em quatro partes, sendo: 1) Identificação do perfil do presidente; 2) Características do Conselho, como número de componentes, tempo de funcionamento, se deliberativos ou consultivos, proporção de membros governamentais e não governamentais, se possuem ou não regimento interno etc., 3) Questões específicas atinentes aos Conselhos relacionadas à Governança eà G overnabilidade locais; 4) Espaço aberto para opiniões dos presidentes. As questões relativas ao item 3 estão associadas a uma escala L ik ert de seis pontos, cuja pontuação corresponde ao seguinte: 1 (discordo totalmente); 2 (discordo muito); 3 (discordo pouco); 4 (concordo pouco); 5 (concordo muito) e 6 (concordo totalmente).

Foi utilizado o programa SPSS versão 15.0 para análise de freqüência das questões objetivas dos questionários. Para as questões abertas, recorreu-se à técnica de análise de conteúdo que objetiva identificar o que está sendo expresso sobre determinado assunto (Vergara, 2005). Trata-se de um método de pesquisa que parte de um conjunto de procedimentos específicos aptos a realizar inferências válidas de textos. As respostas tabuladas eapresentadas em forma estruturada para análise, posteriormente foram interpretadas. Buscou-se identificar, na percepção dos presidentes, como os Conselhos Gestores estão efetivamente desempenhando suas atribuições enquanto mecanismos de controle e de gestão das políticas públicas. Terminada essa etapa realizou-se um work shop com os presidentes, dando-lhes retorno dos resultados apurados e promovendo um debate entre os mesmos. Essa iniciativa permitiu a realização de novas perguntas e obtenção de outros dados e informações que foram úteis para a avaliação do desempenho dos Conselhos.

O s dados secundários, de caráter complementar para essa avaliação, foram coletados nas sínteses dos relatórios de fiscalização de municípios do Estado de Minas $\mathrm{G}$ erais, realizadas pela Controladoria Geral da União (CGU), disponibilizadas no site da instituição (www.cgu.gov.br), correspondendo ao período de 2003 a 2006, quando foram realizados 18 sorteios. Esse Programa de Sorteios Públicos, inovador no governo brasileiro e desenvolvido pela CGU (órgão responsável pelo Sistema de Controle Interno do 
Poder Executivo Federal), tem como objetivos garantir a observância do princípio constitucional da impessoalidade; conscientizar e estimular a sociedade para o controle dos gastos públicos; inibir e dissuadir a corrupção; e coletar dados que indiquem tendências a respeito da execução dos programas de governo.

0 universo da pesquisa foi composto pelos 12 Conselhos Gestores municipais que se encontram em atividade na Cidade de Viçosa (MG), nas áreas de Assistência Social; Cultura e Patrimônio Cultural e Ambiental; D efesa e Conservação do Meio Ambiente; D esenvolvimento Rural Sustentável; Educação; Saúde; Segurança Alimentar e Nutricional; Segurança Pública; Trabalho, Emprego e Geração de Renda; Direitos da Criança e do Adolescente; Portadores de Necessidades Especiais; e Planejamento Municipal.

\section{Resultados e discussão}

\section{Identificação do Penfil dos Presidentes dos Conselhos}

Como primeiro esforço de pesquisa, buscou-se identificar o perfil dos presidentes. Nessa análise foi possível verificar que $83 \%$ têm formação universitária, sendo que $50 \%$ são mestres e/ ou doutores e $16 \%$ fizeram especialização. O s presidentes têm idade média de 50 anos, sendo que a idade mínima registrada é de 29 anos e a máxima, de 69 anos.

Parte significativa dos presidentes, $58 \%$, são servidores públicos da União ou do Município. Entre esses, 71\% são servidores ativos. Três presidentes são também secretários municipais, sendo que dois destes, o da Saúde e o da Educação, dispõem da prerrogativa privativa do exercício da presidência dos Conselhos
Municipais da Saúde e da Educação, conforme estabelecido nos próprios regimentos dos Conselhos.

Há maior incidência de presidentes do sexo masculino, correspondendo a $75 \%$. No que se refere ao estado civil, foi verificado que 75\% dos presidentes são casados e os demais são solteiros.

Com a análise do perfil foi possível constatar que os Conselhos contam com presidentes capacitados e qualificados para o exercício do cargo, pois são pessoas que gozam de experiência na administração pública, possuem conhecimento técnico relacionado às respectivas áreas e capacidade política para coordenar e mediar as negociações e conflitos de interesses que surgem no interior dos Conselhos.

\section{Características dos Conselhos}

Os Conselhos $\mathrm{G}$ estores do município de Viçosa possuem, em média, 12 integrantes, sendo que o número mínimo observado foi de seis e o máximo de 24 membros, com uma média de 11 entidades sendo representadas junto aos mesmos. As reuniões, abertas ao público, são realizadas mensalmente para $75 \%$ dos Conselhos; para os demais ocorrem reuniões bimestrais ou trimestrais. A penas um Conselho não define previamente agenda para as reuniões. A representação nos assentos dos Conselhos segue a proporção de 50\% para membros governamentais e $50 \%$ para membros nãogovernamentais. Uma exceção é o Conselho Municipal de Saúde (CMS) composto pelos seguintes percentuais: $50 \%$ de representantes de entidades dos usuários, $25 \%$ de representantes de entidades dos trabalhadores de saúde e $25 \%$ de representação do governo municipal, conforme a resolução 33/ 92 do Conselho Nacional de Saúde. O utra exceção é o Conselho 
Municipal do Trabalho, Emprego e Geração de Renda, também tripartite e composto por $1 / 3$ de membros governamentais, $1 / 3$ por entidades representativas da classe dos empregados e $1 / 3$ por entidades representativas dos empregadores.

Verificou-se que $100 \%$ dos Conselhos Municipais exercem o papel consultivo, mas apenas $67 \%$ dos mesmos praticam, concomitantemente, o papel deliberativo. Entre estes estão Conselhos como o da Saúde, Meio-Ambiente, Assistência Social, Trabalho, Emprego e G eração de Renda, Criança e Adolescente, Cultura e do Patrimônio Cultural e Ambiental, D esenvolvimento Rural Sustentável e Segurança Alimentar e Nutricional. A prerrogativa para exercerem a função deliberativa deve estar regulamentada na lei que cria 0 Conselho ou em seu regimento interno.

Os Conselhos têm tempo de funcionamento distintos, mas em média funcionam há 10 anos. Os Conselhos da Saúde, e da Criança e do Adolescente são os mais antigos - foram criados em 1991. À exceção dos Conselhos de Segurança Pública, Trabalho, Emprego e G eração de Renda, e Planejamento Municipal, criados na década de 2000, todos os demais foram constituídos nos anos 90.

Nos Conselhos G estores do município de Viçosa, verificou-sea existência de regimento interno que regulamenta 0 funcionamento e as atribuições dos respectivos Conselhos. Observou-se também 0 fiel cumprimento dos mandatos dos conselheiros, com convocações de fóruns próprios nos períodos de novas eleições.

Os Conselhos de Assistência Social, de Saúde e da Criança e do Adolescente realizam a cada dois anos convenção municipal, na qual são verificadas se as metas planejadas para 0 período foram alcançadas, se os planos traçados obtiveram êxito e se as ações implementadas surtiram o efeito desejado nas respectivas áreas de atuação.

Notou-se que $92 \%$ dos Conselhos de Viçosa não dispõem de sede própria e funcionam nas instalações do Poder Executivo. Isso foi considerado por $50 \%$ dos presidentes como "fator que influencia negativamente no desempenho do Conselho". Para solucionar a questão, dois presidentes propuseram a criação da uma "Casa dos Conselheiros", ou seja, um local onde toda infra-estrutura pode ser otimizada, assim como a força de trabalho. No que se refere ao funcionalismo, verificou-se que nenhum Conselho possui um quadro de pessoal próprio, sendo que a força de trabalho utilizada é formada por voluntários, conselheiros ou funcionários do Poder Executivo. Para $75 \%$ dos entrevistados, esse fator também prejudica o desempenho dos Conselhos. Tais constatações nos levam a inferir que a falta de suporte estrutural afeta a atuação dos Conselhos, assim como sua própria independência em relação ao Poder Executivo.

\section{Análise do desempenho dos Conselhos}

$\mathrm{Na}$ primeira etapa da análise do desempenho dos Conselhos, destacaramse as variáveis democratização, descentralização e legitimidade da representação, dimensões fundamentais da discussão sobre os Conselhos.

Conforme demonstrado na Tabela 1, 83\% dos entrevistados concordam muito e/ ou totalmente com a afirmação de que a criação dos Conselhos Gestores em Viçosa possibilitou a democratização dos espaços públicos. O s presidentes ressaltam como importantes mudanças ocorridas nesse sentido: a participação da sociedade 
Tabela 1: Variáveis que compõem a análise: a primeira etapa

\begin{tabular}{|c|c|c|c|c|c|c|}
\hline \multirow{2}{*}{$\begin{array}{l}\text { Demoocfatizaçũo, } \\
\text { descentralizaçẫo e } \\
\text { legitimidade }\end{array}$} & \multicolumn{6}{|c|}{ Freqüéncia relatika na escala arigrinal } \\
\hline & 1 & 2 & 3 & 4 & 5 & 6 \\
\hline 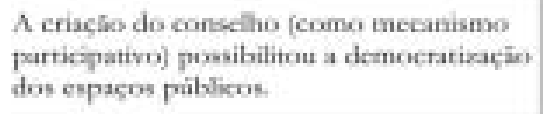 & $0 \%$ & $\theta \%$ & $8 \%$ & $80 \%$ & $39 \%$ & $50 \%$ \\
\hline $\begin{array}{l}\text { A descentralizacio politica e } \\
\text { administrativa costribui pars o } \\
\text { desenvolvimento local. }\end{array}$ & $0 \%$ & $a \%$ & $8 \%$ & $0 \%$ & $6 \%$ & $26 \%$ \\
\hline 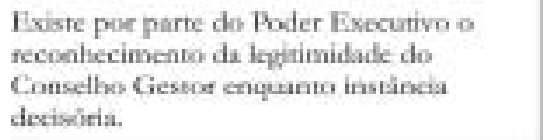 & $\omega \%$ & $0 \%$ & $O_{\mathrm{n}}$ & 176 & $33 \%$ & 5in: \\
\hline 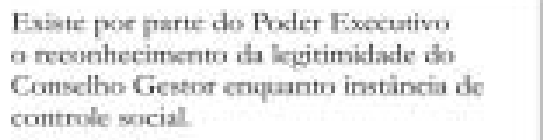 & $1 \%$ & $0 \%$ & Fin & $25 \%$ & tas & $42 \%$ \\
\hline 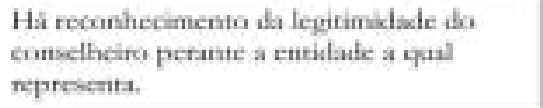 & $10 \%$ & $0 \%$ & $\theta \%$ & $\theta \%$ & $17 \%$ & $8,7 \%$ \\
\hline 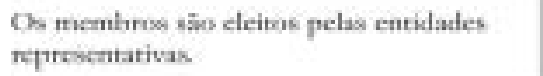 & $\omega$ & $\theta$ & $0 \%$ & $6 \%$ & $8 \%$ & $92 \%$ \\
\hline $\begin{array}{l}\text { O Poder Executivo escree influéneia na } \\
\text { escoltha dos memilnos que tepresentam } \\
\text { as entidades. }\end{array}$ & $100 \% h$ & OTh & $0 \%$ & $\omega_{i n}$ & orib & $0 \%$ \\
\hline
\end{tabular}

Nota: (1) Discordo totalmente (2) Discordo muito (3) Discordo pouco (4) Concordo pouco

(5) Concordo muito (6) Concordo totalmente

Fonte: D ados da Pesquisa

na formulação das políticas sociais marcadas tradicionalmente pelo paternalismo e clientelismo, redefinindo de maneira mais universal e democrática a sua abrangência; a capacidade de iniciativa política, entendida como capacidade de iniciar na agenda política proposições que correspondem às prioridades e/ ou interesses da coletividade; o controle público exercido sobre os atos e programas governamentais; 0 direito de propor, iniciar ou modificar legislação específica, enfim, a publicização e a democratização do acesso ao processo político decisório.
Uma ação prática relatada por presidentes, e que pode ratificar a afirmação feita pelos mesmos quanto à democratização dos espaços com a institucionalização dos Conselhos em Viçosa, foi a criação dos Fundos Municipais dos Direitos da Criança e do Adolescente, da Assistência Social e da Saúde. Esses fundos têm por objetivo facilitar a captação, 0 repasse e as aplicações dos recursos destinados ao desenvolvimento das ações nessas áreas. Os recursos dos Fundos são administrados segundo a política definida pelos respectivos Conselhos que integram o orçamento do município. Estão entre as 
atribuições dos Conselhos em relação aos Fundos: elaboração do plano de aplicação dos recursos, o qual será submetido pelo prefeito à apreciação do Poder Legislativo; estabelecimento dos parâmetros técnicos e as diretrizes para a aplicação dos recursos; acompanhamento e avaliação da execução, desempenho e resultados financeiros do Fundo; mobilização dos diversos segmentos da sociedade no planejamento, execução e controle das ações do Fundo; fiscalização dos programas desenvolvidos com recursos do Fundo; e publicação de todas as resoluções do Conselho referentes ao Fundo em periódicos de grande circulação no município ou afixação em local de fácil acesso à população. Verificou-se também que $92 \%$ dos presidentes de Conselhos entrevistados concordam muito e/ ou totalmente com o fato de que a descentralização contribui para 0 desenvolvimento local. Segundo eles, a municipalização como um processo de descentralização colabora para melhorar a eficácia da gestão pública das políticas sociais. Citaram o Programa de Saúde da Família (PSF), o Programa de Alimentação Escolar e vários Programas de Assistência Social como exemplos de descentralização nas áreas de saúde, educação e assistência social que viabilizam a universalidade do atendimento e a melhoria da qualidade de vida da população.

Para que os Conselhos Gestores possam contribuir para a governabilidade é necessário que estes tenham a sua legitimidade reconhecida pelo Estado e pela sociedade.

A pesar de Souza (2004) inferir que tanto o Poder Executivo quanto o Legislativo tendem a não reconhecer a legitimidade dos Conselhos, invocando uma representação não instituída via sufrágio universal, no município de Viçosa isso parece não ocorrer, pois a grande maioria dos presidentes concorda muito e/ ou totalmente que o Executivo reconhece a legitimidade do Conselho $\mathrm{G}$ estor enquanto instância decisória e de controle social.

Outro aspecto importante da legitimidade diz respeito à escolha independente e democrática dos membros de cada entidade representada no Conselho. Essa questão está relacionada aos quesitos básicos da autonomia da sociedade em relação ao poder público. No município de Viçosa, conforme apurado, os membros não-governamentais são eleitos pelo voto das entidades da sociedade civil representadas nos respectivos Conselhos, reunidas em assembléias convocadas pelo Conselho, mediante edital publicado na imprensa local, no prazo de 15 dias do término do mandato vigente. Assim, verifica-se de fato que o Poder Executivo Municipal não exerce influência na escolha dos membros que representam as entidades, garantindo a independência da sociedade, o exercício da democracia e a transparência no processo de eleição dos representantes da sociedade civil.

O bserva-se ainda, na Tabela 1, que os conselheiros têm sua legitimidade reconhecida pelas entidades que representam, conforme opinaram $100 \%$ dos presidentes entrevistados, dos quais 83\% concordam totalmente e $17 \%$ concordam muito. Tal fato expressa a identidade dos conselheiros com suas bases sociais e, conseqüentemente, o grau da representatividade para discutir e negociar em nome de seu segmento representativo.

Desse modo, o grau de legitimidade apurado nos Conselhos permite inferir que esses mecanismos vêm contribuindo para a governabilidade em Viçosa.

$\mathrm{Na}$ segunda etapa da análise do desempenho dos Conselhos, deu-se ênfase 
Tabela 2: Variáveis que compõem a análise: a segunda etapa

\begin{tabular}{|c|c|c|c|c|c|c|}
\hline \multirow{2}{*}{ 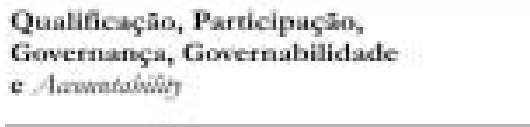 } & \multicolumn{6}{|c|}{$\begin{array}{l}\text { Frequéncia relativa } \\
\text { na escala ariginal }\end{array}$} \\
\hline & 1 & 2 & 3 & 4 & 5 & 6 \\
\hline 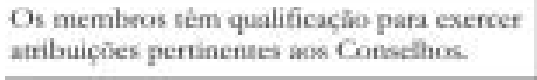 & ofi & $8 \%$ & $\omega \%$ & $42 \%$ & $33 \%$ & $17 \%$ \\
\hline 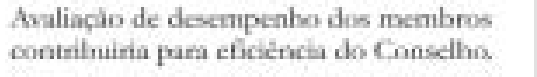 & $0 \%$ & $15 \%$ & $a \%$ & $8 \% 6$ & $29 \%$ & $6 r y$ \\
\hline Os membros șio assiduos às reunices. & $8 \%$ & $8 \%$ & $17 \%$ & $33 \%$ & $17 \%$ & $17 \%$ \\
\hline 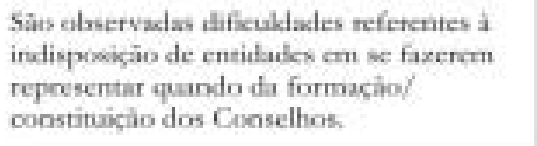 & $17 \%$ & $17 \%$ & $8 \%$ & $8 \%$ & $29 \%$ & $29 \mathrm{~m}$ \\
\hline $\begin{array}{l}\text { OConselho tem contribuido para propor } \\
\text { novas politicas poiblicas (planos/programas/ } \\
\text { perictios) mo setor. }\end{array}$ & $\sigma_{i n}$ & orib & $\pi n$ & $17 \%$ & $29 \%$ & $30 \%$ \\
\hline $\begin{array}{l}\text { O Conselho everce todas as atividade } \\
\text { para as quais foi constituido. }\end{array}$ & $0 \%$ & $8 \%$ & $17 \%$ & $17 \%$ & $33 \%$ & 25\%: \\
\hline $\begin{array}{l}\text { O controle público exercido pelos } \\
\text { Conselhos propiciou melhor aplicaçlo } \\
\text { dos secursos públicos e melhoe } \\
\text { desempenho dus politicas. }\end{array}$ & OKi & $8 \%$ & $\theta \%$ & $17 \%$ & 30\% & $28 \%$ \\
\hline
\end{tabular}

Nota: (1) Discordo totalmente (2) Discordo muito (3) Discordo pouco (4) Concordo pouco (5) Concordo muito (6) Concordo totalmente Fonte: D ados da Pesquisa

aos aspectos da qualificação dos conselheiros e da participação. Conjuntamentea essas dimensões da análise do desempenho, foram focados os temas da governança, governabilidade e accountability - categorias centrais da parte empírica, sobre as quais os Conselhos têm papel fundamental para a prática.

D os presidentes entrevistados, $92 \%$ concordam muito e/ ou totalmente com a afirmação de que a avaliação de desempenho dos conselheiros é uma medida de suma importância para a eficiência produtiva dos Conselhos. Para os presidentes, a identificação dos pontos fortes e fracos apurados na avaliação do desempenho de cada conselheiro permitiria uma intervenção precisa em pontos considerados estratégicos para a eficácia do desempenho coletivo dos Conselhos.

Igualmente importante para a eficácia dos Conselhos, e ainda podendo ser identificada na própria avaliação de desempenho dos conselheiros, está a questão da qualificação, aqui entendida como capacitação. Nota-se, na Tabela 2, que dos 12 presidentes entrevistados seis apontaram a necessidade de uma melhor capacitação para os conselheiros, pois nem todos se encontram suficientemente preparados para discutir e avaliar os interesses envolvidos ou, ainda, para as negociações de conflitos, prioridades e decisões. Além disso, as assimetrias de saber colocam os 
conselheiros menos preparados numa grande dependência de informações, consultas e recursos de toda ordem.

Verifica-se, segundo os presidentes, a necessidade de capacitação técnica dos conselheiros para a formulação e análise das políticas públicas e, também, a capacitação política para melhor avaliar os interesses envolvidos e realizar as alianças eventuais ou estratégicas necessárias à negociação de prioridades e decisões. Essa dupla necessidade de capacitação provoca um salto de qualidade nas representações sociais e, conseqüentemente, na produção dos Conselhos. 0 exercício da argumentação, a fundamentação de suas demandas em critérios de racionalidade pública, a explicitação de conflitos geram uma nova forma de lidar com diferenças e antagonismos dentro desses canais de interlocução, elevando a eficácia dos resultados alcançados na gestão das políticas públicas.

Trata-se de uma questão de extrema importância, haja vista que a capacitação auxilia no desenvolvimento do senso crítico contribui para o melhor atendimento das demandas que surgem da sociedade, permite ao conselheiro ter um maior conhecimento de suas atribuições, além de minimizar as possibilidades de manipulação e cooptação. A capacitação pode estar, também, relacionada aos fatores motivacionais, estimulando a participação política. Acredita-se que o indivíduo politicamente motivado pode dar grandes contribuições para a administração democrática. Já a ausência de capacitação para os conselheiros pode resultar na diminuição da capacidade de controle dos mecanismos e critérios de uso dos recursos públicos, bem como inibir a capacidade de questionamento e reivindicações. Pode, ainda, desfocar a percepção do conselheiro em relação à importância do Conselho e seu verdadeiro papel na sociedade, além de prejudicar o exercício do pensar coletivo.

Os presidentes entrevistados se mostraram sensíveis a essa questão. O bservou-se que três Conselhos já introduziram a prática de capacitação para seus integrantes. A título de exemplo, a presidente do Conselho de Assistência Social relatou que, após a introdução de um programa de capacitação, ocorreram melhorias quanto à assiduidade às reuniões e a aspectos qualitativos da participação, 0 que, conseqüentemente, demonstra 0 efeito positivo da realização de cursos de capacitação. Vale ressaltar que, entre os presidentes entrevistados, $25 \%$ apontaram a capacitação permanente como sugestão para tornar os Conselhos mais efetivos.

Pesquisas revelaram que universidades e organizações não-governamentais têmse empenhado em promover oficinas, seminários e cursos de capacitação para membros de Conselhos Gestores em várias regiões do País, viabilizando a aplicação dos próprios conhecimentos advindos de pesquisas acadêmicas e de programas especiais de treinamento realizados na área dos Conselhos.

Quanto ao interesse participativo da comunidade no que tange aos assuntos e atuação dos Conselhos Gestores, de acordo com a opinião de $90 \%$ dos presidentes, a população de Viçosa ainda não foi despertada para a importância de seu papel na vigilância desses mecanismos de gestão das políticas públicas. Segundo os presidentes, percebe-se infelizmente na cultura política brasileira a predominância de um comportamento acomodado dos cidadãos, que se dão por satisfeitos ao transferir a responsabilidade da gestão dos bens públicos para os políticos e burocratas, não se importando em 
permanecer distantes das arenas de decisões políticas. Essa situação reflete negativamente no desenvolvimento de padrões de cidadania ativa, reforçando a falta de interesse da sociedade em se mostrar vigilante quanto às deliberações e ações desse mecanismo participativo, podendo torná-lo inerte.

$\mathrm{Na}$ percepção dos presidentes, apenas 34\% concordam muito e/ ou totalmente com a afirmação de que os conselheiros são assíduos às reuniões (Tabela 2). Para 66\% dos dos presidentes, ainda falta maior engajamento dos conselheiros. Segundo eles, isso pode ser conseqüência da ausência de capacitação, do incipiente desenvolvimento sociopolítico de alguns segmentos, da carência de moral cívica e de espírito público de alguns membros, entre outros fatores.

A falta de engajamento reflete certo descompromisso com as causas comunitárias. Alterar essa realidade implica mudança de cultura e conscientização política para a necessidade do exercício da cidadania ativa, o que requer tempo. Entretanto, acredita-se que algumas soluções podem ser implementadas para minimizar o problema, tais como desenvolver um programa ou de um plano de incentivos para os conselheiros; dar status à função de conselheiro; estimular o intercâmbio de informações; premiar idéias inovadoras para tornar os Conselhos mais efetivos etc.

Foi observado, ainda, que na formação/ constituição deConselhos éimportante que haja mais mobilização da sociedade civil em se fazer representar e exercer a democracia participativa tão desejada, pois se verificou, junto aos presidentes, certaindisposição para isso por parte de algumas entidades e organizações. Ademais, cinco Conselhos criados no município de Viçosa não estão em atividade devido à indisposição de instituições em se fazerem representar. Tornase indispensável conscientizar as entidades de que o Conselho é um mecanismo fundamental no controle público e talvez sejauma das maiores inovações no processo de democratização dos espaços de deliberação pública. A representação das entidades precisa, a qualquer custo, ser efetivada; caso contrário, não teríamos nos Conselhos a participação de castas importantes e necessárias da sociedade civil na discussão e deliberação de assuntos relevantes para a população. É importante não perder de vista que os Conselhos têm na sua composição a representação de entidades, e não de pessoas.

Conforme verificado na tabela 2, para $75 \%$ dos presidentes os Conselhos têm contribuído com a gestão ao propor novas políticas, projetos inovadores e programas de desenvolvimento para os respectivos setores. Nesse sentido, foram observadas várias ações no município de Viçosa que vêm contribuindo para as práticas da governança e da governabilidade.

Na prática, como se realiza a governança? No caso em análise, ela foi verificada em programas municipais de trabalho, profissionalização e desenvolvimento econômico; em articulações no planejamento e realização de ações entre áreas municipais com interface de atuação; em criação de meios para arrecadação fiscal visando ao fortalecimento de Fundos de atendimento dos direitos da criança e do adolescente; em projetos na educação, compreendendo diversos atores sociais; $\mathrm{e}$ na implementação de programas municipais de assistência social conduzidos pela sociedade e pelo poder público.

A partir do exemplo dos programas municipais de trabalho, profissionalização e desenvolvimento econômico, pode-se 
demonstrar o quanto é promissor, mas também repleto de obstáculos, o caminho para uma governança pública digna desse nome. Em Viçosa, a política municipal de trabalho, emprego e renda é adequada para se avaliar as estruturas de govemança porque é desenvolvida pelo Centro Vocacional Tecnológico (CVT), um projeto de incubação de empresas, no qual várias entidades da sociedade civil participam como parceiras do poder público na promoção do desenvolvimento econômico e da geração de empregos locais. O CVT realiza também cursos profissionalizantes, dando qualificação à mão-de-obra local por meio de parcerias com a Universidade Federal de Viçosa, a Casa do Empresário e a Associação Comercial. A política de trabalho e emprego é atribuição tradicional da União e não das cidades, mas estas há muito tempo têm sido as principais empregadoras. Acima de tudo, precisam superar as conseqüências do desemprego, desastrosas para as cidades.

A intersetorialidade entre as políticas também nos permite avaliar estruturas de governança. As políticas de meio ambiente e de planejamento municipal, em Viçosa, têm-se articulado para melhor exercer o controle e a fiscalização dos empreendimentos imobiliários. A cidade vem crescendo rapidamente e há um forte lobby político da construção civil, que, por vezes, segundo relato de presidentes de Conselhos, tentam sobrepujar a própria legislação ambiental e as leis de edificação. Essa articulação entre as políticas propicia um efeito sinérgico no enfrentamento de problemas complexos e estabelece uma forma de administrar que visa à solução integrada dos problemas.

Também se verificou, em entrevistas com os presidentes de Conselhos, ações articuladas entre as políticas de segurança alimentar e nutricional e de desenvolvimento rural sustentável, no que se refere ao planejamento da produção de alimentos por produtores rurais do município em conformidade com a demanda de programas de alimentação de crianças instituídos no município em creches, escolas, pastorais e associações comunitárias.

O Conselho Municipal dos Direitos da Criança e do A dolescente, utilizando-se de prerrogativas dispostas no Estatuto da Criança e do Adolescente (ECA), lançou, em 2003, uma campanha de arrecadação via renúncia fiscal do imposto de renda de pessoas físicas e jurídicas. A campanha visava ao incremento de novas fontes de receitas para o Fundo Municipal que financia as políticas voltadas ao atendimento dos direitos da criança e do adolescente, em Viçosa.

A viabilização e o crescimento da arrecadação vêm-se dando ano após ano graças a ações de uma rede de cooperação composta por diversos atores sociais. Nesse exemplo, a governança se situa na cooperação por intermédio de redes que podem ser formadas por associações, cidadãos, empresas e segmentos da sociedade na condução de ações para a consecução das políticas. $\mathrm{Na}$ educação, também se observam bons exemplos de governança, fazendo jus ao slogan utilizado pela gestão: "Viçosa, cidade educadora". Há vários projetos de reforço escolar e de cursos de preparação para o vestibular no município, conduzidos por professores voluntários, por pastorais, por universitários e por associações comunitárias em cooperação com o poder público municipal. Essas ações têm impacto direto em questões como evasão escolar, qualidade do ensino e inclusão, aspectos estratégicos de qualquer política educacional. 
Na avaliação das estruturas de governança relacionadas às políticas de assistência social, vislumbraram-se práticas de caráter simples, mas inovadoras e eficientes. D ois programas da política, em Viçosa, chamaram a atenção pela fácil implementação e pelo caráter pouco assistencialista: são o Bolsa Trabalho e 0 Família Viva.

O Bolsa Trabalho visa a atender quem procura a assistência social do município com dificuldades financeiras para suprir determinadas necessidades. Essas pessoas são encaminhadas para executar pequenos serviços avulsos em associações, escolas, empresas, clubes e residências cadastradas no programa e, assim, recebem remuneração. Já o Programa Família Viva oferece cursos que possibilitam à família gerar uma renda extra com a produção artesanal e caseira de vários produtos ou, até mesmo, fazer dessa atividade a base do seu sustento. Segmentos da sociedade são parceiros desta iniciativa, fornecendo matéria-prima e know-how técnico. A ação conjunta, levada a efeito de forma eficaz e compartilhada pelo Estado e pela sociedade civil, almejando uma solução inovadora das demandas e problemas sociais, edifica formas de governança.

No processo de construção da governança, o papel dos Conselhos locais de Viçosa se dá de forma direta, em alguns casos, e indireta, em outros. Não se deve esquecer que os Conselhos compartilham a produção das políticas públicas e sua execução com o Estado. Assim, tanto a responsabilidade pelas políticas quanto os louros colhidos pelos bons resultados que apresentam pertencem a ambos. Sendo governança definida como uma ação conjunta via rede de todos os stak eholders em prol do bem da coletividade, observou-se em Viçosa a prática da boa governança, para a qual os Conselhos locais deram importantes contribuições.

As redes sociais e as alianças municipais, que se formam a partir de organizações, associações, sindicatos, cidadãos e segmentos da sociedade civil, vão dando sustentabilidade e legitimidade a muitas políticas implementadas no município mineiro. Essas entidades que compõem as redes sociais, na maioria das vezes, estão representadas nos assentos dos diversos Conselhos Municipais, conforme observado no estudo, criando uma vasta e rica relação intra e interinstitucionais. As articulações e os apoios formalizados no contexto das políticas públicas em Viçosa sugeriram o alcance de um nível de governabilidade bastante satisfatório, visto que a essência da governabilidade está na capacidade de obter apoios e alianças com os diversos setores da sociedade para legitimar e viabilizar as políticas de um determinado programa de governo.

É notório que a grande força dos Conselhos reside no controle que esses mecanismos podem exercer sobre a ação governamental e a gestão das políticas públicas. Nesse sentido, eles se constituem em um importante instrumento de accountability societal. É pelas entidades da sociedade civil representadas nos Conselhos que são exercidas as influências sobre o sistema político e sobre a burocracia pública, viabilizando, assim, um efetivo controle público do Estado. Para 75\% dos presidentes de Conselhos de Viçosa (Tabela 2), a existência desses mecanismos propiciou melhor aplicação dos recursos públicos e melhor desempenho das políticas, ou seja, o controle exercido pelos Conselhos resultou em maiores benefícios para a sociedade. Entre os benefícios do controle, os presidentes destacam a fiscalização da execução orçamentária, com 
vista à eficiência e à racionalização na aplicação dos recursos; 0 acompanhamento e a fiscalização de processos licitatórios; a verificação das parcerias e/ ou convênios estabelecidos para execução de serviços públicos; e a realização de procedimentos que visam a apurar a probidade e a moralidade de atos na administração.

Para complementar a avaliação do desempenho dos Conselhos em Viçosa foram utilizadas as sínteses dos relatórios de fiscalização de municípios da CGU. Nessas sínteses foram identificados todos os registros pertinentes à atuação dos Conselhos locais em Minas Gerais no período de 2003 a 2006. Verificou-se que os maiores problemas se referem aos Conselhos Municipais de Saúde e Assistência Social. Essa situação pode ser explicada pelo fato de esses Conselhos estarem presentes na maioria dos municípios devido ao repasse de verbas da União e dos Estados a essas áreas estar vinculado à existência dos mesmos. Entre as inúmeras falhas apontadas, destacam-se problemas graves na constituição e operacionalização dos Conselhos, tais como emissão de documentos públicos falsos, omissões na atuação dos Conselhos, irregularidades na formação, ausência de reuniões, cooptação de membros pelo Executivo, não realização de eleições para renovação dos mandatos dos conselheiros, entre outros. Tais problemas resultam na inoperância desses mecanismos nos municípios fiscalizados.

\section{Considerações finais}

Com base na literatura apresentada, verifica-se que o processo de redemocratização do País possibilitou a construção das propostas de democracia participativa e que a criação e a disseminação dos Conselhos G estores municipais são reflexos da necessidade de se reformar as instituições de governo local no Brasil, cujo aspecto central requer maior participação direta da sociedade na gestão dos municípios e na formulação das políticas públicas.

0 estágio de desenvolvimento das diversas políticas públicas é distinto porque o processo de municipalização não vem ocorrendo de modo uniforme para todas elas. A transferência de equipamentos e recursos federais e estaduais para o município é feita de maneira isolada, de acordo com cada política. Isso tem repercussões na gestão, pois o município acaba reproduzindo tal fragmentação na gestão de cada política setorial, refletindo, assim, as condições em que se encontram, individualmente. Partindo do pressuposto de que as necessidades dos cidadãos não são satisfeitas apenas pela intervenção de uma política, é preciso promover a interação das diversas ações setoriais para resolver os problemas na sua totalidade e permitir ao cidadão melhor qualidade de vida.

A conclusão de efeitos mais imediatos dos Conselhos depende da natureza com que os mesmos se revestem, conforme 0 caráter que lhes dá a lei responsável por sua criação. D esse modo, quanto mais autonomia dispuserem para deliberar sobre 0 setor da gestão pública de sua competência, maior será a sua eficácia enquanto canais de instrumentalização de poder popular. Assim, a natureza deliberativa dos Conselhos figura como relevante para que suas decisões e orientações possam culminar em resultados democráticos mais efetivos.

A democracia participativa significa bem mais que pleitear o direito de assento nos espaços de negociação dos interesses públicos. Significa construir uma cultura política democrática fortalecida, em 
especial, pelo exercício da cidadania ativa. Nesse sentido, há dois aspectos que vêm à tona quanto à participação: entidades e conselheiros. Muitas vezes os Conselhos têm seu funcionamento inviabilizado porque as entidades que deveriam compôlos não apresentam seus respectivos representantes. Surgem diante desse episódio duas possibilidades de tal desinteresse: ou há poucas entidades para muitos Conselhos ou as entidades priorizam determinados Conselhos de acordo com seus interesses. Essa dúvida pode ser um bom incentivo para realização de outros trabalhos na área. No que se refere à participação dos conselheiros, a dificuldade de quórum em reuniões é uma realidade não muito rara. Existe a necessidade de se instituir alguns incentivos para a função como forma de reconhecimento de sua importância no processo de gestão das políticas públicas.

Os Conselhos são estruturas jurídicoconstitucionais, de caráter permanente, que fazem parte da estrutura orgânica do poder público. Possuem atribuições políticas, mas também administrativas. Para realizar com maior autonomia suas funções administrativas, sugere-se tanto a construção de infra-estrutura própria para os Conselhos quanto a contratação de mão-de-obra, propiciando-lhes um formato de órgão, não estatal, integrado ao aparato público.

As cidades são as maiores responsáveis pela convergência de aplicações dos modelos de governança das políticas públicas para lidar com a demanda cada vez maior de novas exigências dos cidadãos. As parcerias e alianças, realizadas no âmbito municipal, dão substância às estruturas de governança e legitimidade às políticas públicas intentadas, fortalecendo também a capacidade de governar. As políticas públicas sempre terão melhores chances de alcançar suas finalidades quando geridas por um modelo de gestão pública que pressupõe que o Estado étão mais eficiente quanto mais democrática for a sua administração. 0 tema da accountability por meio dos seus instrumentos de aplicação, entre os quais os próprios Conselhos Gestores, viabilizam não apenas o controle das ações governamentais, mas também a eficiência estatal e a democratização das relações entre Estado e sociedade. A governança, a governabilidade e a accountability formam um tripé estratégico que faz a diferença para o êxito das políticas públicas.

Os Conselhos locais analisados neste estudo nos revelaram resultados que demonstraram poucas distorções entre a teoria aplicada ao tema dos Conselhos e a sua efetiva prática no campo público. Com isso, pôde-se constatar que esses mecanismos de participação instituídos no município de Viçosa têm galgado importantes degraus de desenvolvimento e aperfeiçoamento. A pesquisa demonstrou, porém, que o grau de desenvolvimento institucional dos Conselhos não é homogêneo. Há Conselhos melhores gestores que outros, e isso se deve a um conjunto de fatores, como natureza deliberativa, capital social, descentralização da política, conectividade da política setorial com programas de governo e estruturas de governança implantadas.

Vimos, no decorrer deste trabalho, que os Conselhos em Viçosa têm possibilitado a democratização dos espaços públicos via inclusão de segmentos da sociedade, outrora excluídos da arena pública.

A escolha independente e democrática dos membros não-governamentais dos Conselhos revela a condição essencial para sua independência do Poder Executivo. Os Conselhos em Viçosa têm-se legitimado perante a sociedade e aos poderes 
instituídos como mecanismos independentes, não servindo de correias de transmissão das decisões do Executivo.

Contudo, a capacitação de conselheiros precisa ser implementada, pois nem todos se encontram plenamente preparados para 0 exercício da função com a qualidade desejada. Essa assimetria da qualificação é prejudicial para o interesse público, pois desequilibra as discussões e negociações no interior dos Conselhos, podendo desfigurar sua característica colegiada, colocando-os à mercê de prejuízos e riscos desnecessários.

O grau e a forma de governança verificada na gestão de várias políticas públicas em Viçosa merecem destaque. As redes sociais formadas por Conselhos, associações, cidadãos, organizações e instituições públicas dão conta não apenas das estruturas de governança, mas também do nível de governabilidade e da efetividade da accountability.

A realização deste balanço nos permitiu avaliar que o desempenho dos Conselhos Gestores de Viçosa é bem satisfatório. Para ratificarmos a presente conclusão, fizemos ainda uma comparação, baseada nos mesmos critérios de avaliação, com Conselhos de várias cidades mineiras que compõem as sínteses dos relatórios de fiscalização de municípios do Estado, realizadas pela CGU.

(Artigo recebido em maio de 2007. Versão final em julho de 2008).

\section{Referências bibliográficas}

ARRETCHE, Martha. Políticas Sociais no Brasil: descentralização em um Estado Federativo. Revista Brasileira de Ciências Sociais, n. 40, v. 14, p. 111-141, 1999.

Mitos da descentralização: mais democracia e eficiência nas políticas públicas? Revista Brasileira de Ciências Sociais, n. 31, ano XI, p. 44-66, 1996.

Banco Mundial. Relatório sobre desenvolvimento mundial e pobreza. Reunião do Comitê Executivo. México 2002.

. Más Allá D el Centro: la descentralización del Estado. Estúdios D el Banco Mundial sobre América Latina y Caribe. Puentos de vista. Washington, D. C., 1999. Bento, Leonardo Valles. Governança e governabilidade na reforma do Estado: entre eficiência e democratização. Barueri, SP: Manole, 2003.

Bresser Pereira, Luis Carlos; Spink, Peter Kevin. Reforma do Estado e administração pública gerencial. 6. ed. Rio de Janeiro: FGV, 2005.

BReSSer PereiRa. D isponível em <http:/ / www.bresserpereira.org.br/ ver_file.asp?id=281>. CÂMARA Municipal de ViçoSA. Disponível em <http:/ / www.camaravicosa.mg.gov.br/ ?area $=$ cidade $>$.

Carneiro, Carla Bronzo Ladeira; Costa, Bruno Lazzarotti Diniz. Inovação institucional e accountability: 0 caso dos conselhos setoriais. In:VI Congreso Internacional del CLAD sobrela Reforma del Estado y de la Administración Pública, Buenos Aires, Argentina, 5-9 nov. 2001 CARvalho, Antônio Ivo. Conselhos de Saúde no Brasil: participação cidadã e controle social. Rio de Janeiro: Ibam/ Fasae, 1995. 
Carvalho, José Murilo de. Os Bestializados. São Paulo: Cia. das Letras, 1987.

Coelho, Magda; Diniz, Eli. Governabilidade, Governança Local e Pobreza no Brasil. Rio de Janeiro, IUPERJ, 1995.

Constituição/ 1988 - Constituição da República Federativa do Brasil: 1988. 13. ed. Brasilia: Câmara dos Deputados, Coordenação de Publicações, 2000.

D Agnino, Evelina. Anos 90 - Política e Sociedade no Brasil. São Paulo: Brasiliense, 1994.

D InIZ, Eli. G overnabilidade, D emocracia e Reforma do Estado: Os D esafios da Construção de uma Nova Ordem no Brasil dos Anos 90. In: Dados - Revista de Ciências Sociais. Rio de Janeiro, v. 38, n. 3, p. 385-415. 1995.

Diniz, Eli; Azevedo, Sérgio. Reforma do Estado e D emocracia no Brasil: dilemas e perspectivas. UnB/ ENAP, 1995.

D ormo, Ana Maria. A Vez e a Voz do Popular - Movimentos sociais e participação política no Brasil pós- 70. Rio de Janeiro: Relume - D umará: ANPOCS. 1995.

Fuks, Mário; Perissinotto, Renato Monseff; Souza, Nelson Rosário. (orgs.). D emocracia e participação: os conselhos gestores do Paraná. Curitiba: UFPR, 2004.

G enro, Tarso. A Utopia Possível. 2. ed. Porto Alegre: Artes e O fícios Editora. 1995.

Goнn, Maria da Glória. Conselhos Gestores e Participação Sociopolítica. 2. ed. São Paulo: Cortez, 2003. (Coleção questões da nossa época; v.84)

. Teoria dos Movimentos Sociais. São Paulo: Loyola, 1997.

G RAU, Nuria Cunnil. Módulos críticos da accontability societal - extraindo lições de sua institucionalização na América Latina. In: A responsabilização na nova gestão pública. CLAD-BID, 2000.

Guimarães, Tomas de Aquino. A nova administração pública e a abordagem da competência. Revista de Administração Pública. Rio de Janeiro, FGV, 34(3): 125-40, Maio/Jun. 2000.

Instituto Brasileiro de Geografia e Estatística - IBGE. Disponível em <http:/ / www.ibge.gov.br/ home/ >.

JanN, Werner. G overnance. In: Eichhom, Peter (org.). Verwaltungslexikon, 3. ed. Aufe. Baden Baden, p. 449-451, 2003.

KeIneRT, Tânia Margarete Mezzomo. Os paradigmas da administração pública no Brasil (1900-1992). Revista de Administração de Empresas, v. 34, n. 3, p. 41-48. 1994.

LÖFFER, Elke. G overnance: die newe generation von staatsund Verwaltungs - modern isierung. Verwaltung + Management, v. 7, n. 4, p. 212-215, 2001.

Lubambo, Cátia Wanderley. Conselhos G estores e D esempenho da Gestão nos Municípios: Potencialidades e Limites. Trabalhos para discussão n. 149/ 2002, setembro, 2002. Disponível em <http:/ / www.fundaj.gov.br

Noronha, Rudolf de. Avaliação Comparativa dos Conselhos Municipais. In: Conselhos G estores de Políticas Públicas, São Paulo, Polis, n. 37, 2000.

Novelli, Ana Lúcia Romero. 0 papel institucional da comunicação pública para 0 sucesso da governança. Revista Brasileira de Comunicação O rganizacional e Relações Públicas, ano 3, série 4, p. 74-89, 2004. 
O ’D onnell, Guilhermo. Notas sobre várias accountabilities. Mimeo. 2000. . Sobre o corporativismo e a nação do Estado. Cadernos DCP. Belo Horizonte: Departamento de Ciência Política da UFMG, 1976.

Rofman, Alejandro. Aspectos Conceptuales sobre D escentralización Político-administrativa en America Latina, In: Seminario-Taller sobre: D escentralización de los Servicios de Salud como estrategia para el Desarollo delos sistemas Locales de Salud, Q uito, maio/ junho 1990.

SADER, Eder. Quando novos personagens entram em cena: experiências, falas e lutas dos trabalhadores da Grande São Paulo, 1970-1980. Rio de Janeiro: Paz e Terra, 1988. Santos Jr., O rlando Alves dos; Ribeiro, Luiz César de Queiroz; Azevedo, Sérgio. G overnança democrática e poder local: a experiência dos conselhos municipais no Brasil. Rio de Janeiro: Revan, Fase, 2004.

SANTOS, Mauro Rego Monteiro dos. Conselhos municipais: a participação cívica na gestão das políticas públicas. Dissertação. (Mestrado). Programa de Mestrado da Universidade Federal do Rio de Janeiro. Instituto de Planejamento Urbano e Regional. Rio de Janeiro: UFRJ, 2000.

SomarRiBa, Mercês. Movimento Reivindicatório Urbano e Política em Belo Horizonte. In: Neves, Magda de Almeida e Dulci, Otávio Soares (org.). Belo Horizonte: Poder, Política e Movimentos Sociais, Belo Horizonte: c/ Arte. 1996.

Teixeira, Elenaldo Celso. Sistematização: Efetividade e Eficácia dos Conselhos. In: Conselhos G estores de Políticas Públicas, São Paulo, Polis, n. 37, 2000.

Telles, Vera da Silva. Sociedade Civil e a Construção de Espaços Públicos. In: D Agnino, Evelina (org.). Os anos 90: Política e Sociedade no Brasil, São Paulo: Brasiliense, 1994.

Vergara, Sylvia Constant. Projetos e Relatórios de Pesquisa em Administração. São Paulo: Atlas, 1997.

. Métodos de Pesquisa em Administração. São Paulo: Atlas, 2005. 


\section{Resumo - Resumen - Abstract}

\section{Conselhos Municipais de Políticas Públicas: uma análise exploratória}

M arcelo Feijó M artins, Simone M artins, A driel Rodrigues de 0 liveira e Jéferson Boechat Soares

O s Conselhos $\mathrm{G}$ estores são fóruns híbridos onde se viabiliza a participação popular no desenho das políticas públicas, nas negociações de interesses da coletividade, na elaboração de programas e projetos sociais e na fiscalização das ações governamentais. 0 significado e a dimensão dos Conselhos para a democracia participativa são enormes, justificando a importância da realização deste estudo, que se baseou na análise exploratória de 12 Conselhos locais do município mineiro de Viçosa, com o objetivo de avaliar o desempenho dos mesmos. A avaliação do desempenho levou em consideração os mesmos parâmetros dimensionais, tanto para a coleta de dados primários quanto para a coleta secundária. A coleta de dados primários foi realizada a partir da aplicação de questionários semi-estruturados aos presidentes dos Conselhos em análise. Utilizou-se o programa SPSS, versão 15.0, para análise estatística das questões objetivas dos questionários e a técnica de análise de conteúdo para exame das questões abertas. A pós essa etapa, realizou-se um work shop com os presidentes dos Conselhos, visando à obtenção de novos dados e informações. Os Conselhos municipais analisados apresentaram resultados pouco discrepantes entre a teoria aplicada ao tema e a sua efetiva prática no campo público. Contudo, a pesquisa revelou que o grau de desenvolvimento institucional dos Conselhos não é homogêneo, ou seja, há alguns melhores gestores que outros. A escolha independente e democrática dos membros não-governamentais dos Conselhos em Viçosa revelou o seu grau de independência do Poder Executivo. Porém, a capacitação de conselheiros precisa ser implementada para evitar uma desfiguração dos Conselhos. No que tange à governança, destacouse em Viçosa o seu grau e formas de aplicabilidade observadas na gestão de várias políticas. Da mesma forma, foi observado um nível de governabilidade que confere legitimidade às políticas implementadas. Por fim, verificou-se que a efetividade da accountability societal tem sido instrumentalizada pelos Conselhos no âmbito das diversas políticas setoriais. Já os dados secundários da análise foram obtidos por meio das sínteses dos relatórios de fiscalização de municípios do Estado de Minas G erais, realizadas pela Controladoria Geral da União. Foram identificados todos os registros pertinentes aos Conselhos G estores Municipais do Estado de Minas G erais, no período de 2003 a 2006. Verificou-se que os maiores problemas se referem aos Conselhos Municipais de Saúde e Assistência Social. Entre as inúmeras falhas apontadas, destacam-se problemas graves na constituição e operacionalização dos Conselhos, resultando na inoperância desses mecanismos nos municípios fiscalizados. A avaliação do desempenho dos Conselhos locais de Viçosa possibilitou concluir que esses mecanismos apresentaram um desempenho bem satisfatório na gestão e controle das políticas públicas no município.

Palavras-chave: Conselhos G estores; G overnança; G overnabilidade

\section{Consejos municipales de políticas públicas}

M arcelo Feijó M artins, Simone Martins, A driel Rodrigues de 0 liveira y Jéferson Boechat Soares

Los consejos gestores son foros híbridos donde se viabiliza la participación popular en: el dibujo de políticas públicas, en las negociaciones que interesan a la colectividad, en la elaboración de programas y proyectos sociales, y en la fiscalización de las acciones de gobierno. El significado y la importancia delos consejos es muy grande parala democracia participativa, lo cual justificala realización de este trabajo que se basó en el análisis de 12 consejos municipales del município de Viçosa en Minas $\mathrm{G}$ erais. El referido trabajo calificó el desempeño de los consejos. La evaluación de desempeño llevó en cuentalos mismos parámetros dimensionales para recoger los datos primários y secundários. La recogida de datos primários fue realizada aplicando cuestionarios semi estructurados a los 
presidentes de los consejos. Fue usado el programa SPSS, versión 15.0 para el análisis estatístico de las preguntas directas del cuestionario, y la técnica de análisis de contenido para el análisis de las preguntas " abiertas". D espués de esa etapa se hizo un " workshop" con los presidentes de los consejos para o btener nuevos datos e informaciones. Los consejos municipales evaluados mostraron resultados semejantes entre la teoria y la práctica. A un así la investigación mostró que el desarrollo institucional de los consejos no es homogéneo, o sea, hay consejos que son mejores gestores que otros. La elección democrática e independiente de los representantes no gubernamentales de los consejos de Viçosa mostró la independencia de estos ante el poder ejecutivo. Apesar de esto, es necesário que los consejeros sean entrenados para evitar la desfiguración de los consejos. En lo que se refiere a la gobernanza, se ha destacado en Viçosa la aplicabilidad de esta en la gestión de diferentes políticas. También se há observado una gobernabilidad que dá legitimación a las políticas públicas. Por último se ha verificado que la efectividad del accountability societal se ha llevado a cabo en los consejos en el ámbito de políticas sectoriales. Los datos secundários del análisis se obtuvieron por la síntesis de informes de fiscalización de los municipios del estado de Minas $\mathrm{G}$ erais hechos por la "Controladoria Geral da União". Fueron identificados todos los registros que se refieren a los consejos gestores municipales del estado de Minas $\mathrm{G}$ erais en los años de 2003 a 2006. Se ha verificado que los más grandes problemas son los consejos municipales de salud y de asistencia social. Entre los errores señalados se destacan los problemas en la formación y funcionamiento de los consejos, lo que resulta en el no-funcionamiento de esos consejos en los municípios fiscalizados. La evaluación de desempeño de los consejos de Viçosa concluyó que estos tienen um buen desempeño en la gestión y en el control de las políticas públicas en el municipio.

Palabras clave: consejos gestores, gobernanza, gobernabilidad

\section{Municipal Councils for Public Policies: an exploratory analysis}

M arœelo Feijó M artins, Simone M artins, A driel Rodrigues de O liveira and Jéferson B oechat Soares

Management Councils are hybrid forums where popular participants get involved with the design of public policies, with negotiations of collective interests, with the elaboration of programs and social projects, and with the supervision of governmental actions. The meaning and dimension of Councils to participatory democracy are enormous, justifying the importance of this study, based on an exploratory analysis of 12 local Councils on the municipality of Viçosa (in Minas G erais state, Brazil). The goal is to evaluate the performance of these Councils. The performance evaluation took into consideration the same dimensional parameters, to both collecting primary data and to secondary data. Primary data collection was through the application of semi-structured questionnaires, to Council presidents of the Councils under research. Program SPSS was used (version 15.0) to the statistical analyses of the multiple-choice questions, and the technique of content analyses was used to the open questions. After this phase, a workshop took place with the Council presidents, aiming at obtaining new data and information. The Municipal Councils researched showed results with little discrepancies between the theory applied to the issue and the effective practice in the public arena. However, research showed a not-homogeneous institutional development levels councils. That is, there are councils which are better than others. The independent and democratic choice of Council non-governmental members revealed its independence level from the Executive Brach. In spite of that, it is necessary to capacitate the counselors in order to avoid the disfiguration of the councils. As to governance, Viçosa highlighted the degree and forms of applicability observed in the management of several policies. Similarly, a level of governability was observed, which confers legitimacy to the policies implemented. It was in the end verified that the effectiveness of societal accountability has been used by Councils in the arena of several sector-specific policies. As for the secondary data of analyses, they were obtained through a synthesis of supervisory reports by the $\mathrm{G}$ eneral Controlling $\mathrm{O}$ ffice, on the Minas G erais State's municipalities. All records related to municipal 
councils were identified, in Minas G erais state from the year 2003 to the year 2006. The main problems refer to the municipal councils on health and social assistance. Among the many faults appointed, the gravest problems are in the constitution and operational routines of councils, resulting on the non-function of these mechanisms in the supervised municipalities. The performance evaluation of Viçosa local councils led to the conclusion that those mechanisms present areasonable good performance for management and control of public policies in the municipality.

Key words: Management councils, governance, governability

Marcelo Feijó Martins

Graduado e Mestrando em Administração de Empresas pela Universidade Federal de Viçosa (UFV).

Contato: m_feijo@yahoo.com.br

Simone Martins

Professora Assistente da Universidade Federal dos Vales do Jequitinhonha e Mucuri (UFVJM). Graduada em Ciências Contábeis na Universidade Federal de Minas Gerais (UFMG), Mestre em Administração pela Universidade Federal de Viçosa (UFV)

Contato: simonemartins_yahoo.com.br

Adriel Rodrigues de Oliveira

D outor em Administração pela Universidade de São Paulo. Professor Adjunto do Departamento de Administração da Universidade Federal de Viçosa (UFV).

Contato: aroli@ufv.br

Jéferson Boechat Soares

Doutor em Sociologia pela Universidade Federal do Rio de Janeiro. Professor Adjunto do Departamento de Economia da Universidade Federal de Viçosa (UFV).

Contato: jb_soares@ hotmail.com 